\title{
1 Metabolic strategies of sharing pioneer bacteria mediating fresh
}

\section{2 macroalgae breakdown}

3

4 Maéva Brunet ${ }^{1}$, Nolwen Le Duff ${ }^{1}$, Tristan Barbeyron ${ }^{1}$ and François Thomas $^{1 \#}$

5

$6 \quad{ }^{1}$ Sorbonne Université, CNRS, Integrative Biology of Marine Models (LBI2M), Station

7 Biologique de Roscoff (SBR), 29680, Roscoff, France.

8

9 Running head: bacterial degradation of fresh macroalgae

10

11 \#Address correspondence to François Thomas, francois.thomas@sb-roscoff.fr

12

13 The authors have no conflict of interest to declare. 


\section{Abstract}

15 Macroalgae represent huge amounts of biomass worldwide, largely recycled by marine

16 heterotrophic bacteria. We investigated the strategies of "pioneer" bacteria within the

17 flavobacterial genus Zobellia to initiate the degradation of fresh brown macroalgae, which has

18 received little attention compared to the degradation of isolated polysaccharides.

19 Zobellia galactanivorans Dsij $^{\mathrm{T}}$ could use macroalgae as a sole carbon source and extensively

20 degrade algal tissues without requiring physical contact, via the secretion of extracellular

21 enzymes. This indicated a sharing behaviour, whereby pioneers release public goods that can

fuel other bacteria. Comparisons of eight Zobellia strains, and strong transcriptomic shifts in

Z. galactanivorans cells using fresh macroalgae vs. isolated polysaccharides, revealed

potential overlooked traits of pioneer bacteria. Besides brown algal polysaccharide

degradation, they notably include stress resistance proteins, type IX secretion system proteins and novel uncharacterized Polysaccharide Utilization Loci. Overall, this work highlights the relevance of studying fresh macroalga degradation to fully understand the niche, metabolism and evolution of pioneer degraders, as well as their cooperative interactions within microbial communities, as key players in macroalgal biomass turnover.

\section{$31 \quad$ Introduction}

32 Macroalgae are major primary producers in coastal zones, acting as a global carbon sink (1).

33 Specific polysaccharides dominate macroalgal extracellular matrices (ECM) and can represent up to $50 \%$ of the dry weight (2). For example, brown algae produce alginates and fucose-containing sulfated polysaccharides (FCSPs). Alginates are linear polymers of $\beta$-Dmannuronic (M) and $\alpha$-L-guluronic acids $(\mathrm{G})$, representing between 10 and $45 \%$ of the algal dry weight (2). FCSPs, accounting for 4-13\% of the dry weight (3), refer to linear or highly 
branched polysaccharides containing $\alpha$-linked L-fucose residues together with a variety of other neutral monosaccharides constituents (galactose, mannose, xylose, rhamnose, etc.) and uronic acids (4). They present many substituents, mainly sulfate and acetyl groups. The structure of brown algal polysaccharides is consequently highly heterogeneous and varies according to species, seasons, geographical locations, thallus part, algal growth stages and environmental factors (3-7). Within the ECM, these carbohydrates are cross-linked and associated with proteins (3-15\%), minerals (7-36\% such as iodine, calcium, iron, copper and magnesium), phenols (1-13\%), vitamins, amino acids and small amounts of lipids (1-5\%) to form a complex matrix (8-11). Besides ECM polysaccharides, brown algae also produce laminarin ( $\beta$-1,3-glucan) and mannitol (12) as storage carbohydrates.

Marine heterotrophic bacteria are crucial for algal biomass mineralization (13). Macroalgae surfaces are constantly colonized by diverse bacterial communities with densities varying from $10^{2}$ to $10^{7}$ cells $\mathrm{cm}^{-2}$ of macroalgal tissue (14). A fraction of these communities, mainly Bacteroidetes, Gammaproteobacteria, Verrucomicrobia and Planctomycetes, can degrade this complex biomass, showing abilities to hydrolyze purified high molecular weight algal compounds using a considerable enzymatic arsenal (15-18). Over the last 20 years, many studies investigated the algal polysaccharide-processing capabilities of marine heterotrophic bacteria (19), deciphering new catabolic pathways and unraveling the role of carbohydrate active enzymes (CAZymes, http://www.cazy.org, (20)) including glycoside hydrolases (GHs), polysaccharide lyases (PLs) or carbohydrate esterase (CEs), and sulfatases (http://abims.sbroscoff.fr/sulfatlas/, (21)). In Bacteroidetes, CAZymes are usually organized within clusters of coregulated genes involved in carbohydrate binding, hydrolysis and transport, known as Polysaccharide Utilization Loci (PULs). The regulations of these PULs during purified algal substrate degradation were recently studied in a few transcriptome-wide analyses, for both cultivated marine bacteria (22-26) and natural seawater bacterial communities (27). However, 
using unique substrates does not reflect the complexity of the responses that might occur during the degradation of intact algal biomass. Considering the algae as a whole could reveal novel genes and catabolic pathways, not induced by soluble purified polysaccharides, but playing key roles in algal biomass recycling in the field. To date information on the mechanisms involved in raw algal material assimilation is scarce. "Bacillus weihaiensis" $\mathrm{Alg} 07^{\mathrm{T}}$ and Bacillus sp. SYR4 grow with kelp and red algal powder, respectively $(23,28)$ and Microbulbifer CMC-5 grows with thallus pieces of the red alga Gracilaria corticata (29). These studies suggested a successive use of the different brown algal polysaccharides contained in the algal ECM (23) and the release of degradation product in the medium $(28,29)$. However, to our knowledge, no previous work investigated the metabolic mechanisms involved in the degradation of fresh macroalgae, hindering our understanding of algal biomass recycling in coastal habitats. Recently, it has been suggested that among bacteria that are able to use soluble algal compounds, only some populations might be specialists for the breakdown of intact macroalgae tissue (19,30,31). This so-called pioneer bacteria would initiate tissue degradation and expose new substrate niches for less efficient community members considered as scavengers.

The genus Zobellia (Flavobacteriaceae family) is frequently found associated with macroalgae and can account for up to $8 \%$ of natural bacterial communities on decaying algae (32-34). It is composed of 15 validly described strains classified in 8 species (35-38). Their genomes encode numerous CAZymes (263-336 genes representing from 6.4 to $7.6 \%$ of the coding sequences), and sulfatases (39-41). Therefore, Zobellia spp. are considered as potent algal polysaccharide degraders. In particular, Zobellia galactanivorans $\mathrm{Dsij}^{\mathrm{T}}$, isolated from a red macroalga $(35,42)$, is a model strain to study macroalgal polysaccharide utilization (43). It allowed the discovery of many novel CAZymes and the description of new PULs targeting alginates (44-46), carrageenans $(25)$, agars $(47,48)$, laminarin $(49,50)$, mix-linked glucan $(51)$ 
and mannitol (52). Its complete transcriptome analysis revealed common regulations triggered by polysaccharides from the same algal phylum (24). Z. galactanivorans $\mathrm{Dsij}^{\mathrm{T}}$ is also well equipped to cope with algal defenses and can accumulate iodine $(39,53,54)$. Moreover, a previous study suggested that Z. galactanivorans $\mathrm{Dsij}{ }^{\mathrm{T}}$ would act as a pioneer bacteria by initiating the breakdown of the kelp Laminaria digitata, and demonstrated the crucial role of the alginate lyase AlyA1 in this process (55).

In this study, we aim to better understand the mechanisms controlling fresh macroalgae degradation. To tackle this issue, (i) the complete transcriptome of Z. galactanivorans Dsij ${ }^{\mathrm{T}}$ was analyzed during the degradation of three brown macroalgae with distinct chemical composition and compared with purified sugars to decipher key genes and mechanisms specifically triggered on fresh tissues and (ii) the ability of Z. galactanivorans to degrade fresh algae tissues was compared with other Zobellia spp. to assess its singular behavior and hypothesize on potential genetic determinant in fresh macroalgae breakdown.

\section{Experimental procedure}

\section{Purified substrates}

Maltose (Sigma-Aldrich, St. Louis, MO, USA), alginate from Laminaria digitata (Danisco [ref. Grindsted FD176], Landerneau, France) and FCSPs from Ascophyllum nodosum (Algues \& Mer [HMWFSA15424, fraction > $100 \mathrm{kDa}$ ], Ouessant, France) were tested for growth. Treatment of this commercial FCSP extract with the alginate lyase AlyA1 (45) followed by Carbohydrate-PAGE (56) revealed it contained alginate impurities. Colorimetric assays $(57,58)$ showed that uronic acids accounted for approximately $24 \%(\mathrm{w} / \mathrm{w})$ of the FCSP extract. Based on previous measurements of $9 \%$ uronic acid content in pure FCSPs from $A$. nodosum (59), we therefore estimated the alginate contamination in the FCSP extract to be ca. 
111 15\%. Alginate, agar (Sigma-Aldrich), kappa- (Goe $\square$ mar, St. Malo, France) and iota-

112 carrageenans (Danisco) were used for enzymatic assays.

\section{Strains}

114 Bacterial strains used in this study are listed in SuppTable1, together with previous results of

115 their ability to use pure algal compounds (35-37). They were first grown in Zobell 2216

116 medium (60) at room temperature before inoculation in marine minimum medium (MMM)

117 complemented with antibiotics to which all the tested Zobellia strains are resistant (see

118 supplementary methods for composition) and amended with 4 g. $\mathrm{l}^{-1}$ maltose as the sole carbon

119 source. Pre-cultures were centrifuged (3200 g, $10 \mathrm{~min})$ and pellets washed twice in 1X saline

120 solution. Cells were inoculated in microcosms at $\mathrm{OD}_{600} 0.05$.

\section{Macroalgae treatment}

122 Healthy Laminaria digitata, Fucus serratus and Ascophyllum nodosum were collected in May

1232019 at the Bloscon site $\left(48^{\circ} 43^{\prime} 29.982^{\prime}\right.$ ' N, 03 $58^{\circ} 8.27^{\prime \prime}$ W) in Roscoff (France) and cut in

124 pieces (ca. $2.5-3.5 \mathrm{~cm}^{2}$ ) with a sterile scalpel. To clean them from resident epibionts, algal

125 pieces were immersed in $0.1 \%$ Triton in milli-Q water for $10 \mathrm{~min}$ followed by $1 \%$ iodine

126 povidone in milli-Q water for $5 \mathrm{~min}$. Finally, algal pieces were rinsed in excess autoclaved

127 seawater for 2 hours, to remove algal exudates and metabolites that could have been produced

128 upon cutting.

\section{Microcosm set up and sampling}

130 All experiments were performed in triplicates, except for $F$. serratus in duplicates, at $20{ }^{\circ} \mathrm{C}$ in

131 MMM with macroalgae pieces as the sole carbon source. Z. galactanivorans was grown in 50

$132 \mathrm{ml}$ with 10 macroalgal pieces, either young L. digitata $(<20 \mathrm{~cm})$, F. serratus or A. nodosum.

133 For comparison it was also grown in the same conditions using $4 \mathrm{~g} . \mathrm{l}^{-1}$ maltose, alginate or

134 FCSPs. During the exponential phase, culture medium $(10 \mathrm{ml})$ and algal pieces were retrieved 
135 separately on ice for RNA extraction from the free-living and algae-attached bacteria,

136 respectively. On ice, 0.5 volume of killing buffer $(20 \mathrm{mM}$ Tris- $\mathrm{HCl} \mathrm{pH} 7.5,5 \mathrm{mM} \mathrm{MgCl} 2,20$

$137 \mathrm{mM} \mathrm{NaN}_{3}$ ) was added to the liquid samples and cell pellets were frozen in liquid nitrogen.

138 Algal pieces were washed twice in killing buffer: $\mathrm{H}_{2} \mathrm{O}(1: 1)$ and frozen in liquid nitrogen.

139 Samples were stored at $-80{ }^{\circ} \mathrm{C}$ until RNA extraction. To assess Z. galactanivorans growth

140 when cultivated in contact or physically separated from algal tissues, incubations were

141 performed in two-compartment vessels (100 $\mathrm{ml}$ each) with round bottom and a $65 \mathrm{~mm}$ flat

142 edge opening (Witeg [ref. 0861050], Wertheim, Germany), separated by a $0.2 \mu \mathrm{m}$ filter. Each

143 compartment was filled with $30 \mathrm{ml}$ of MMM and ten L. digitata pieces were immersed in one.

144 For comparative physiology, the eight Zobellia strains were grown in $10 \mathrm{ml}$ with three $L$.

145 digitata pieces from the meristem part $(<15 \mathrm{~cm}$ from the base).

\section{RNA extraction and sequencing}

147 Details of the protocols are available in Supplementary Methods. Briefly, free-living bacterial

148 cells were lysed by incubation $5 \mathrm{~min}$ at $65^{\circ} \mathrm{C}$ in lysis buffer $(400 \mu \mathrm{l})$ and phenol $(500 \mu \mathrm{l})$.

149 After phenol-chloroform extraction, RNA was treated $1 \mathrm{~h}$ at $37^{\circ} \mathrm{C}$ with 2 units of Turbo

150 DNAse (ThermoFisher Scientific, Waltham, MA, USA), purified using NucleoSpin RNA

151 Clean-up (Macherey-Nagel, Hoerdt, France) and eluted in $50 \mu$ l of nuclease-free water.

152 RNA from algae-attached bacteria was extracted as follows. Two algal pieces were immersed

153 in killing buffer, vortexed and placed $7 \mathrm{~min}$ in an ultrasonic bath to detach bacteria from the

154 algal surface. Algae were removed and cell pellets resuspended in lysis buffer. RNA

155 extraction and DNAse treatment were performed as described above for the free-living

156 bacteria. To avoid RNA loss on purification columns, DNAse was inactivated using the

157 DNAse inactivation reagent (ThermoFisher Scientific).

158 DNA contamination was checked by PCR with primers S-D-Bact- 0341-b-S-17 and S-D-

159 Bact-0785-a-A-21 targeting the 16S rRNA gene (61). RNA was quantified using the Qubit 
160 RNA HS assay kit (ThermoFisher Scientific) and its integrity assessed on a Bioanalyzer 2100

161 (Agilent Technology, Santa Clara, CA, USA) with the Agilent RNA 6000 Pico kit.

162 Paired-end RNA sequencing (RNA-seq) was performed by the I2BC platform (UMR9198,

163 CNRS, Gif-sur-Yvette) on a NextSeq instrument (Illumina, San Diego, CA, USA) using the

164 NextSeq 500/550 High Output Kit v2 (75 cycles) after a Ribo-Zero ribosomal RNA depletion

165 step. A total of 24 samples were sequenced (SuppTable 2). Sequencing failed for sample

166 Att_Ldig2 due to poor sample quality.

\section{RNA-seq analysis}

168 Demultiplexed and adapter-trimmed reads were processed with the Galaxy platform 169 (https://galaxy.sb-roscoff.fr). After read quality filtering using Trimmomatic v0.38.0, 170 transcripts were quantified using the pseudo-mapper Salmon v0.8.2 (62) with the $Z$. 171 galactanivorans $\mathrm{Dsij}^{\mathrm{T}}$ reference genome (retrieved from MicroScope 172 “zobellia_gal_DsiJT_v2”; Refseq NC_015844.1). Raw counts for individual samples were 173 merged into a single expression matrix for downstream analysis. Raw and processed data 174 were deposited under GEO accession number GSE189322. Principal Component Analysis 175 (PCA) and differential abundance analyses were performed on rlog-transformed data using 176 DESeq2 v1.26.0 package (63) in R v3.6.2 (64). Genes displaying a log2 fold-change $|\log 2 \mathrm{FC}|$ $177>2$ and a Bonferroni-adjusted P-value $<0.05$ were considered to be significantly 178 differentially expressed. The upset plot was done using the ComplexUpset package $(65,66)$.

179 Hierarchical clustering was performed using the Ward's minimum variance method (67). 180 Graphics were prepared using ggplot2 (68).

\section{Enzymatic assays}

182 One volume of $0.2 \mu \mathrm{m}$ filtered supernatant from the microcosms was incubated with 9 183 volumes of $0.2 \%$ polysaccharide substrate at $28{ }^{\circ} \mathrm{C}$ overnight. Controls were prepared with 
184 boiled supernatants. The amount of reducing ends released was quantified using the

185 ferricyanide assay (69). For each sample, the activity measured in controls was subtracted.

186 Finally, the mean value $(n=3)$ measured for the non-inoculated microcosms was subtracted.

187 Significant differences $(\mathrm{P}<0.05)$ from 0 were tested using t-tests.

\section{CARD-FISH}

189 Algal pieces and culture medium were fixed overnight at $4{ }^{\circ} \mathrm{C}$ with $2 \%$ paraformaldehyde.

190 Free-living bacteria were harvested on a $0.2 \mu \mathrm{m}$ polycarbonate membrane. Catalyzed reporter

191 deposition-fluorescence in situ hybridization (CARD-FISH) was performed as described in

192 (34) using the Zobellia-specific probe ZOB137 with helpers. Cells on membrane were

193 visualized with a Leica DMi8 epifluorescent microscope (oil objective 63X). Cells on algal

194 tissues were detected with a Leica TCS SP8 confocal microscope (HC PL APO 63X/1.4 oil

195 objective) using the 488 and $638 \mathrm{~nm}$ lasers to detect Alexa488 signal and algal

196 autofluorescence signal, respectively. Z-stack images were collected using 1024x1024 scan

197 format $(0.29 \mu \mathrm{m}$ thick layers, $400 \mathrm{~Hz}$ scan speed $)$ and visualized using the surface channel 198 mode of the 3D viewer module (Leica Las X software).

\section{Comparative genomics}

200 Zobellia genomes were screened for GHs, PLs, CEs and sulfatases using dbCAN2 (70) on the 201 MicroScope platform (https://mage.genoscope.cns.fr). Homologs ( $>50 \%$ identity and $>80 \%$ 202 alignment) were searched for genes of interest using synteny results on MicroScope. 


\section{Results}

\section{Zobellia galactanivorans Dsij ${ }^{T}$ degrades and utilizes fresh brown}

\section{5 macroalgae tissues as carbon source}

206 Z. galactanivorans growth was tested with three brown macroalgae from two different orders

207 and with distinct chemical composition, Laminaria digitata (order Laminariales), Fucus

208 serratus and Ascophyllum nodosum (order Fucales), as the sole carbon and energy source.

209 Growth was detected with the three algal species $(\mathrm{OD} \approx 0.2-0.5$, Figure $1 \mathrm{~A})$, with tissue

210 bleaching and damages only visible on L. digitata pieces after $65 \mathrm{~h}$ (Figure 1B). Zobellia-

211 specific CARD-FISH assays revealed that even if antibiotic-resistant resident epibionts grew

212 in the non-inoculated controls containing A. nodosum and F. serratus (one replicate), most of

213 the bacterial biomass after $65 \mathrm{~h}$ in the Zobellia-inoculated microcosms was Zobellia cells (>

$21450 \%$, SuppFigure 1).

215 CARD-FISH assays on $L$. digitata tissues showed gradual tissue colonization by $Z$.

216 galactanivorans, from cell patches at the surface of the L. digitata mucilage coat to deeper

217 penetration within the tissue invading the intercellular space (Figure 1C).

\section{Transcriptomic shift during fresh macroalgae degradation}

Z. galactanivorans $\mathrm{Dsij}^{\mathrm{T}}$ transcriptome of free-living cells obtained during macroalgal degradation was compared to the responses occurring with a disaccharide, maltose, and with purified brown algal polysaccharides, alginate and FCSPs. Between 44 and $93 \%$ of the

222 sequenced reads from free-living bacteria grown with macroalgae mapped on the genome of

223 Z. galactanivorans $\mathrm{Dsij}^{\mathrm{T}}$ (SuppTable 2). Multivariate analysis separated samples according

224 to carbon source (Figure 2A). Transcriptomes of cells grown with $L$. digitata were closer to

225 that obtained with alginate of FCSPs compared to A. nodosum or F. serratus. 
226 Differential abundance analysis revealed 1117 and 864 genes up- and down-regulated with at

227 least one substrate, using maltose as control (SuppTable 3). Among them, $56 \%$ (628 up-

228 regulated genes) and $52 \%$ (449 down-regulated genes) showed substrate-specific regulations

229 (Figure 2B). In particular, half of the genes regulated with A. nodosum and FCSPs were not

230 differentially expressed in any other conditions. L. digitata was the algae inducing the highest

231 number of regulations shared with at least one polysaccharide (399, 254 and 217 genes with

232 L. digitata, F. serratus and A. nodosum respectively). More regulations were shared between

233 L. digitata and $F$. serratus (116 genes) than $F$. serratus and A. nodosum (89 genes) or $L$.

234 digitata and A. nodosum (13 genes). Finally, a core set of 70 up-regulated and 59 down-

235 regulated genes responded to the three macroalgae.

\section{Carbohydrate catabolism-related genes}

237 Hierarchical clustering of expression data of the 51 identified PULs in the Z. galactanivorans

$238 \mathrm{Dsij}^{\mathrm{T}}$ genome revealed that PULs predicted to target brown algal polysaccharides grouped

239 together (Figure 3A) and were significantly induced with macroalgae. In particular, the

240 alginate-specific PUL29 was significantly overexpressed in all conditions compared with

241 maltose (mean $\log 2 \mathrm{FC}$ of 4 ) and the highest expression was observed with L. digitata (Figure

242 3B, SuppFigure 2). Some PULs were exclusively triggered by macroalgae: PUL34 and 35,

243 likely targeting FCSPs (as they encode sulfatases and fucosidases), were significantly

244 triggered by $L$. digitata, PUL4 targeting $\beta$-glucan responded to A. nodosum and the FCSP

245 PUL3 was induced by both L. digitata and F. serratus. PUL26 and 27, whose function

246 remains unclear, were both induced by L. digitata and FCSPs, as well as by alginate for

247 PUL26 and F. serratus for PUL27. Purified FCSPs also induced the expression of 14 PULs

248 outside the described cluster, encompassing a large diversity of targeted substrate (notably $\beta$ -

249 and $\alpha$-glucan, sulfated polysaccharides, xylan, unclear substrate). No PUL known to target red

250 algal polysaccharides (e.g. PUL40, 42, 49 or 51) clustered with this set of overexpressed 
251 PULs, suggesting a specific induction of brown algal polysaccharide degradation mechanisms

252 in the presence of brown algal tissues. The measured activity of secreted polysaccharidases

253 corroborates this observation (Figure 3C), as only the alginolytic activity was significantly

254 higher when Z. galactanivorans was grown on macroalgae compared with the non-inoculated

255 control (t-test, $\mathrm{P}<0.05)$.

256 On the other hand, PULs targeting simple sugars (maltose and fructose) or polysaccharides

257 absent from brown algae (starch and chitin) were repressed with macroalgae and purified

258 polysaccharides (Figure 3A). The starch PUL12 was strongly underexpressed in all 259 conditions while the chitin PUL31 showed a significant repression only with algal 260 polysaccharides.

261 Specific induction with fresh algal tissues

262 To unravel pathways specifically governing the degradation of fresh macroalgal biomass, we

263 further focused on genes upregulated with at least one macroalgal species compared to 264 maltose and purified polysaccharides. We detected 41, 59 and 189 genes following this 265 pattern with L. digitata, F. serratus or A. nodosum, respectively (SuppTable 4). It included 266 few CAZyme-encoding genes (Figure 4), notably two genes within putative FCSP PULs 267 (zgal_205 [GH117 in PUL3] and zgal_3445 [GH88 in PUL34]). Other polysaccharidase 268 genes outside classical PUL structures were induced with A. nodosum, such as alyAl 269 (zgal_1182, alginate lyase PL7), cgaA (zgal_3886, glucan 1,4-a-glucosidase GH15), agaC 270 (zgal_4267, $\beta$-agarase GH16), pelA1 (zgal_3770, pectate lyase PL1) and dssA (zgal_3183, 271 sheath polysaccharide lyase PL9). GT2 (zgal_2991,4154) and GT4 (zgal_2990,3759) were 272 also triggered with macroalgae. Additionally, many genes linked to oxidative stress responses 273 and Type IX secretion systems (T9SS) were specifically induced with macroalgae (Figure 4). 274 A large gene cluster (zgal_1071-1105) notably encoding three oxidoreductases, a DNA 275 topoisomerase and a peroxiredoxin was up-regulated with L. digitata and F. serratus. Other 
276 genes encoding antioxidant proteins were triggered, especially on L. digitata, such as the

277 superoxide dismutase SodC (ZGAL_114) or a $\beta$-carotene hydroxylase (ZGAL_2972), as well

278 as a carboxymuconolactone decarboxylase family protein (ZGAL_1598) which includes

279 enzyme involved in antioxidant defense (71). Two catalases (ZGAL_1427 and ZGAL_3559)

280 were induced in the presence of $L$. digitata and F. serratus in comparison to maltose and

281 alginate (SuppTable4). Several genes predicted to encode T9SS components were

282 significantly induced during macroalga degradation, in particular with A. nodosum (14 out of

28333 genes identified in the genome, against 1 and 5 with $L$. digitata and $F$. serratus

284 respectively) (Figure 4). They include particularly genes encoding SprF family proteins and

285 T9SS-associated PG1058-like proteins. In addition, 7 unknown proteins containing a

286 conserved C-terminal domain (CTD) from families TIGR04131 (gliding motility -

287 ZGAL_2022, 2761, 2762, 3727) and TIGR04183 (Por secretion system - ZGAL_93, 1124,

288 4310) were triggered. These CTDs are typical of cargo proteins secreted by the T9SS.

\section{Effect of bacterial attachment to macroalgae}

291 Transcriptomes of algae-attached cells were compared to that of free-living bacteria. To

292 minimize bias due to poor sequencing depth (caused by a high proportion of eukaryotic rRNA

293 in algae-attached samples [SuppTable 2]), we discarded samples from A. nodosum

294 microcosms (up to $70 \%$ of uncovered coding regions) and only considered upregulated genes

295 (not the down-regulated ones) in attached versus free-living bacteria. Respectively 19 and 14

296 genes were significantly induced in bacteria attached to L. digitata or F. serratus (Figure

297 5A), including a shared set of 5 genes from a genomic region (zgal_4237-4246) putatively

298 involved in stress responses. Attachment to L. digitata induced the expression of two TetR-

299 type transcriptional regulators, 2 YceI family proteins which might be involved in oxidative

300 stress response via isoprenoide synthesis $(72,73)$ and 5 chaperones (Figure 5A). Cells 
301 attached to $F$. serratus notably overexpressed 2 TonB-dependent receptors not associated with

302 a SusD-like protein, likely not involved in carbohydrate metabolism.

303 To assess if algal degradation requires biofilm formation, Z. galactanivorans was grown

304 either in contact or physically separated from algal pieces (Figure 5B). After 6 days, algal

305 tissues were visually starting to decompose when bacteria were separated from algae,

306 although to a lesser extent compared to the "contact" condition. Furthermore, extracellular

307 alginolytic activity increased even without physical bacteria/algae contact and reached similar

308 levels to that observed in the "contact" condition after $90 \mathrm{~h}$.

309 Comparative physiology and genomics of fresh macroalga degradation by

$310 \quad$ Zobellia

311 The degrading abilities of other members of the genus Zobellia were investigated

312 (Figure 6A). All tested Zobellia strains used fresh L. digitata tissues for their growth. $Z$.

313 galactanivorans $\mathrm{Dsij}^{\mathrm{T}}$ had the highest final cell density $\left(\mathrm{OD}_{600}=1.5\right)$ and shortest generation

314 time $\left(5.09\right.$ h). Z. nedashkovskayae Asnod3-E08-A formed cell aggregates that biased $\mathrm{OD}_{600}$

315 readings, likely explaining the apparent limited growth (final $\mathrm{OD}_{600}=0.4$ ) and long

316 generation time $\left(\mathrm{t}_{\mathrm{gen}}=16.33 \mathrm{~h}\right)$. Other strains showed intermediate behaviors $\left(\mathrm{OD}_{600} \approx 1,5.92\right.$

$317<\mathrm{t}_{\text {gen }}<11.74 \mathrm{~h}$ ). These growth differences were reflected in the final aspect of macroalgal

318 pieces. Only Z. galactanivorans $\mathrm{Dsij}^{\mathrm{T}}$ completely broke down algal tissues after $91 \mathrm{~h}$. Both $Z$.

319 nedashkovskayae strains caused limited algal peeling and breakdown at the corners of the

320 pieces., No visible trace of degradation was detected for other strains. A strong negative

321 correlation was found between the number of GHs and the generation time (Spearman, rho = -

322 0.90; $\mathrm{P}=0.006$ ) (Figure 6A, SuppTable 5). Twenty-two out of the 305 genes up-regulated

323 by Z. galactanivorans Dsij $^{\mathrm{T}}$ with $L$. digitata compared to maltose had no homologs in the

324 genome of the seven other Zobellia strains (SuppTable 6). They include two GHs, zgal_3349 
325 (GH20 in PUL33) and zgal_3470 (GHnc in PUL35), and a susCD-like pair (zgal_3440, 3441)

326 in PUL34. Other up-regulated genes within the FCSP PUL34/35 are not conserved in all

327 Zobellia strains (Figure 6B). Likewise, several alginolytic genes were not conserved across

328 the genus, especially in the two Z. roscoffensis strains that lack 7 of them. zgal_1182 and

329 zgal_4327, encoding the extracellular endo-alginate lyases AlyA1 and AlyA7 respectively,

330 were not conserved in the other strains (zgal_4327) or only found in the Z. nedashkovskayae

331 strains (zgal_1182). Two other genes related to carbohydrate assimilation (zgal_334 and

332 zgal_2296 encoding a GHnc and a lipoprotein with CBM22, respectively) are missing in five

333 strains (SuppTable 6). zgal_334 neighbors genes encoding sulfatases, fucosidases and PLs

334 and might belong to a FCSP-targeting cluster (absent from the 51 identified PULs as the pair

335 susCD-like is absent).

\section{Discussion}

337 Zobellia galactanivorans Dsij $^{\mathbf{T}}$ acts as a sharing pioneer in brown

\section{8 macroalgae degradation}

339 By degrading macroalgae, marine heterotrophic bacteria are central to nutrient cycling in

340 coastal habitats. The ecological strategies of different functional guilds not equally equipped

341 to process biomass were recently conceptualized $(19,30,31)$. First, pioneer bacteria degrade

342 complex organic matter by producing specific hydrolytic enzymes. The hydrolysate can then

343 fuel other bacteria called exploiters or scavengers, which cannot feed on intact substrates.

344 Such cooperative interactions were previously characterized during alginate (74) or chitin

$345(75,76)$ assimilation. Hence, in nature pioneer bacteria likely control the initial attack on fresh

346 macroalgae, a hitherto rarely studied process that cannot be fully deciphered when using

347 purified polysaccharides or crushed algae. Here, we showed that Z. galactanivorans Dsij $^{\mathrm{T}}$

348 uses healthy brown algal tissues for its growth, highlighting its pioneer role in algal biomass 
349 recycling. Similar growth rates were observed with three brown algal species, and $Z$.

350 galactanivorans completely broke down L. digitata tissues. Transcriptomes obtained with $L$.

351 digitata were closest to that with alginate and FCSP, suggesting a greater capacity to access

352 and digest ECM polysaccharides within the L. digitata tissues compared to A. nodosum and $F$.

353 serratus. The limited degradation of Fucales tissues might originate from their higher

354 phlorotannin content (77), possibly inhibiting CAZymes (78). In addition, A. nodosum

355 induced a wider cellular response with many specific regulations. This might partly be due to

356 the growth of antibiotic-resistant epiphytic bacteria that could have affected $Z$.

357 galactanivorans behavior or to its much thicker and rigid thallus. Furthermore, A. nodosum is

358 associated with various symbionts, especially the obligate endophytic fungus Mycophycias

359 ascophylli (79) that secretes compounds potentially preventing tissue grazing and/or offering

360 new substrate niches.

361 We showed that although Z. galactanivorans can colonize L. digitata, it does not require a

362 physical contact to initiate degradation. Furthermore, only few upregulated genes were

363 detected in surface-attached vs. free-living cells. While difficulties to extract RNA from

364 algae-attached bacteria resulted in poor sequencing coverage, it should still have been

365 possible to detect strong upregulations in attached cells. Overall, our results indicate that

366 surface attachment is not required for the utilization of algal biomass by Z. galactanivorans

$367 \mathrm{Dsij}^{\mathrm{T}}$. This suggests a crucial role for secreted enzymes to initiate degradation, in line with the

368 measured extracellular alginolytic activity. Constitutively expressed extracellular enzymes,

369 such as the alginate lyases AlyA1 and AlyA7 (44), would rapidly release diffusible

370 degradation products, allowing remote substrate sensing. We previously showed that $Z$.

371 galactanivorans accumulates low molecular weight (LMW) alginate oligosaccharides when

372 grown with purified alginate and algal tissues $(44,55)$. Our results therefore confirms that $Z$.

373 galactanivorans would be a "sharing" pioneer providing degradation products as public goods 
to other taxa (55), contrary to "selfish" pioneers which sequester LMW products by producing essentially surface-associated hydrolytic enzymes with minor loss of hydrolysate to the medium $(80,81)$.

We further evidenced that this pioneer behavior can be strain-specific within the algaassociated genus Zobellia. All Zobellia spp. tested successfully grew with fresh L. digitata but without causing pronounced tissues damages as observed with Z. galactanivorans. Their catabolic profiles (SuppTable 1) indicate different growth capacities with purified brown algal sugars. For example, Z. roscoffensis strains and Z. laminariae KMM $3676^{\mathrm{T}}$ display limited or no abilities to use alginate, FCSPs and laminarin for their growth. Hence, with macroalgae, they likely did not use these complex polysaccharides but rather fed on soluble algal exudates (e.g. mannitol). Comparative genomics suggested that CAZyme content influences the strain capacity to use and break down fresh algal tissues. In particular, some strains lack homologs of overexpressed genes contained in L. digitata-induced PULs targeting alginate or FCSPs. For example, alyAl homologs were only found in the two other strains that caused visible algal damage (Z. nedashkovskayae Asnod2-B07-B ${ }^{\mathrm{T}}$ and Asnod3-E08-A). Accordingly, alyAl is known to have a crucial role in initiating algae breakdown (55). Such genes would therefore represent potential genetic determinants of pioneer bacteria.

\section{Deciphering the metabolic mechanisms involved in fresh tissue breakdown,}

\section{including new catabolic pathways}

Regardless of the algal species, the well-characterized alginolytic PUL29 was the most induced among all PULs. Alginate is the most abundant polysaccharide in brown algal ECM and likely the most accessible as it embeds the cellulose-FCSP network (11). This PUL was particularly triggered with $L$. digitata, likely reflecting the higher alginate content in this species (2) and/or an easier substrate accessibility. Furthermore, several uncharacterized PULs were triggered with macroalgae. Three out of the seven predicted FCSP PULs were 
399 significantly upregulated with macroalgae but not with extracted A. nodosum FCSPs, and to

400 various degrees depending on algal species. In addition, two PULs with unclear function

401 (PUL26 and 27) were induced with both FCSPs and macroalgae. This suggests different

402 substrate specificities, consistent with the large structural diversity of FCSPs and cross-

403 linkage to other compounds $(4,7,82)$ which might not be equally extracted during purification.

404 By preserving the original polysaccharide structure and environment, the study of fresh

405 macroalga degradation may therefore be a more effective way to reveal specific genes crucial

406 for macroalgae breakdown by pioneer bacteria but undetectable when using purified

407 polysaccharides.

408 By contrast to alginate- and FCSP-targeting PULs, the characterized laminarin PUL11 and

409 PUL28 were poorly regulated with the three algae. An uncharacterized $\beta$-glucan PUL4 was

410 significantly induced only with A. nodosum, and also found triggered with purified laminarin

411 in a previous study (24). As raised above, the presence of endosymbionts in A. nodosum could

412 result in specific laminarin structures that might be targeted by PUL4. The absence of

413 induction of typical laminarin PULs with macroalgae might also indicate that $Z$.

414 galactanivorans $\mathrm{Dsij}^{\mathrm{T}}$ first uses ECM polysaccharides and later access intracellular storage

415 polysaccharides. Such a prioritization of multiple substrates within algal material was

416 previously observed for Bacillus weihaiensis $\mathrm{Alg} 07^{\mathrm{T}}$ grown on algal powder (23). Koch et al.

417 (26) showed that Alteromonas macleodii 83-1 prioritized laminarin over alginate and pectin

418 when grown on a mixture of purified polysaccharides. Thus, prioritization might differ

419 between bacterial strains and whether substrates are under soluble form or within algal tissues,

420 underlining the importance to consider intact macroalgae to understand the pioneer behavior.

421 Furthermore, future time-resolved transcriptome analyses could inform on regulations at

422 different degradation stages and help decipher prioritization effects. 
423 Besides carbohydrate utilization, our approach unveiled several traits specifically induced

424 upon macroalgal degradation and potentially linked to the pioneer behavior, including the

425 resistance to algal defense and T9SS. One of the algal defense mechanisms is the production

426 of reactive oxygen species (ROS), which in L. digitata is partly induced by endogenous

427 elicitors (i.e. oligo-alginates) derived from the degradation of their own cell wall (83).

428 Breakdown of $L$. digitata tissues by Z. galactanivorans likely produced large amounts of

429 elicitors and consequently triggered a massive oxidative burst, in line with the strong

430 induction of genes encoding ROS-detoxifying enzymes in this condition. In contrast, $A$.

431 nodosum and $F$. serratus do not respond to the addition of endogenous elicitors (84),

432 potentially explaining the lower induction of antioxidant pathways in Z. galactanivorans

$433 \mathrm{Dsij}^{\mathrm{T}}$ with these algae. Another algal defense response is the emission of halogenated

434 compounds. One vanadium-dependent iodoperoxidase (vIPO3) and a haloacid dehalogenase

435 (HAD, (54)) were significantly up-regulated with A. nodosum compared with alginate and

436 maltose respectively. HAD expression was also 3-fold higher with $L$. digitata and $F$. serratus

437 compared to maltose, although large variations precluded significance. The induction of stress

438 resistance mechanisms was even more pronounced in bacteria attached to L. digitata tissues

439 through the expression of chaperones. Overall, our results suggest that pioneer bacteria might

440 have evolved to cope with increasing stress levels upon algal degradation. By metabolizing

441 toxic compounds, they might favor the growth of less stress-resistant scavenger bacteria, a

442 hitherto overlooked additional benefit besides the opening of new substrate niches.

443 Specific to Bacteroidetes, T9SS is involved in biofilm formation, protease virulence factors

444 delivery and secretion of polysaccharidases and cell-surface gliding motility adhesins $(85,86)$.

445 Here, we showed that growth with macroalgae strongly induced genes encoding T9SS

446 components, T9SS-translocated proteins and several glycosyl transferases from families GT2

447 and GT4. Glycosyltransferases with a GT4_CapM-like domain were recently shown to N- 
448 glycosylate CTD in Cytophaga hutchinsonii, an essential step for the recognition of cargo

449 proteins by T9SS (87). Hence, our data suggest T9SS might be a key determinant of pioneer

450 behavior in the Bacteroidetes phylum, to secrete ECM-targeting CAZymes and/or attach to

451 macroalgal surfaces.

\section{Conclusion}

453 This study provides the first insights into the metabolic strategies of sharing pioneer bacteria 454 during fresh macroalgae utilization and represents a source of potential genetic determinants 455 for further functional characterization. Altogether, our results raised the relevance to consider 456 the whole complexity of macroalgae tissues in further degradation studies, as it would take a

457 step forward in the understanding of the algal biomass recycling through the identification of 458 new metabolic pathways or the characterization of bacterial cooperative interactions.

\section{Acknowledgments}

461 The authors thank Tatiana Rochat for advice during transcriptomic analyses, Sébastien Colin 462 for guidance in confocal manipulation, Philippe Potin and Cécile Hervé for helpful 463 discussions and Yan Jaszczyszyn from the I2BC sequencing platform. This work has 464 benefited from the facilities of the Genomer platform and from the computational resources of 465 the ABiMS bioinformatics platform (FR 2424, CNRS-Sorbonne Université, Roscoff), which 466 are part of the Biogenouest core facility network. This work was funded by the French 467 Government via the National Research Agency programs ALGAVOR (ANR-18-CE02-0001468 01) and IDEALG (ANR-10-BTBR-04). 
470 The authors have no conflict of interest to declare.

471 Author contributions (according to CRediT taxonomy)

472 Conceptualization: MB, TB and FT. Data curation: MB, FT. Formal analysis: MB, FT.

473 Funding acquisition: FT. Investigation: all authors. Supervision: TB, FT. Visualization: MB.

474 Writing original draft: MB. Writing review and editing: MB, TB and FT.

\section{References}

477 1. Duarte C, Middelburg JJ, Caraco N. Major role of marine vegetation on the oceanic $478 \quad$ carbon cycle. Biogeosciences. 2005;2:1-8.

479 2. Kloareg B, Quatrano RS. Structure of the cell walls of marine algae and ecophysiological functions of the matrix polysaccharides. Ocean Mar Biol Annu Rev. 1988;26:259-315.

4. Deniaud-Bouët E, Hardouin K, Potin P, Kloareg B, Hervé C. A review about brown algal cell walls and fucose-containing sulfated polysaccharides: Cell wall context, biomedical properties and key research challenges. Carbohydr Polym. 2017;175:395408.

5. Haug A, Larsen B, Smidsrød O. Uronic acid sequence in alginate from different sources. Carbohydr Res. 1974;32(2):217-25. 
fucoidan content in two North Atlantic kelp species, Saccharina latissima and Laminaria digitata - seasonal variation and impact of environmental factors. J Appl Phycol. 2017;29(6):3121-37.

7. Ponce NMA, Stortz CA. A comprehensive and comparative analysis of the fucoidan compositional data across the Phaeophyceae. Front Plant Sci. 2020;11:556312.

8. Fleurence J. The enzymatic degradation of algal cell walls: A useful approach for improving protein accessibility? J Appl Phycol. 1999;11(3):313-4.

9. Verhaeghe EF, Fraysse A, Guerquin-Kern JL, Wu T Di, Devès G, Mioskowski C, et al. Microchemical imaging of iodine distribution in the brown alga Laminaria digitata suggests a new mechanism for its accumulation. J Biol Inorg Chem. 2008;13(2):25769.

10. Schiener P, Black KD, Stanley MS, Green DH. The seasonal variation in the chemical composition of the kelp species Laminaria digitata, Laminaria hyperborea, Saccharina latissima and Alaria esculenta. J Appl Phycol. 2015;27(1):363-73.

11. Deniaud-Bouët E, Kervarec N, Michel G, Tonon T, Kloareg B, Hervé C. Chemical and enzymatic fractionation of cell walls from Fucales: Insights into the structure of the

12. Michel G, Tonon T, Scornet D, Cock JM, Kloareg B. Central and storage carbon metabolism of the brown alga Ectocarpus siliculosus: Insights into the origin and evolution of storage carbohydrates in Eukaryotes. New Phytol. 2010;188(1):67-81. California Press. 1982. 
513 14. Egan S, Harder T, Burke C, Steinberg P, Kjelleberg S, Thomas T. The seaweed 514 holobiont: Understanding seaweed-bacteria interactions. FEMS Microbiol Rev. $515 \quad 2013 ; 37(3): 462-76$.

516 15. Kirchman DL. The ecology of Cytophaga-Flavobacteria in aquatic environments. $517 \quad$ FEMS Microbiol Ecol. 2002;39(2):91-100.

16. Thomas F, Hehemann JH, Rebuffet E, Czjzek M, Michel G. Environmental and gut Bacteroidetes: The food connection. Front Microbiol. 2011;2:93.

17. Teeling H, Fuchs BM, Becher D, Klockow C, Gardebrecht A, Bennke CM, et al.

21. Barbeyron T, Brillet-Guéguen L, Carré W, Carrière C, Caron C, Czjzek M, et al. for sulfatases reflecting their substrate specificity. PLoS One. 2016;11(10):1-33. 
535 22. Tang K, Lin Y, Han Y, Jiao N. Characterization of potential polysaccharide utilization $536 \quad$ systems in the marine Bacteroidetes Gramella flava JLT2011 using a multi-omics approach. Front Microbiol. 2017;8:220.

23. Zhu Y, Chen P, Bao Y, Men Y, Zeng Y, Yang J, et al. Complete genome sequence and transcriptomic analysis of a novel marine strain Bacillus weihaiensis reveals the mechanism of brown algae degradation. Sci Rep. 2016;6:38248.

24. Thomas F, Bordron P, Eveillard D, Michel G. Gene expression analysis of Zobellia galactanivorans during the degradation of algal polysaccharides reveals both substratespecific and shared transcriptome-wide responses. Front Microbiol. 2017;8:1808.

25. Ficko-Blean E, Préchoux A, Thomas F, Rochat T, Larocque R, Zhu Y, et al. Carrageenan catabolism is encoded by a complex regulon in marine heterotrophic bacteria. Nat Commun. 2017;8:1685.

26. Koch H, Dürwald A, Schweder T, Noriega-Ortega B, Vidal-Melgosa S, Hehemann JH, et al. Biphasic cellular adaptations and ecological implications of Alteromonas macleodii degrading a mixture of algal polysaccharides. ISME J. 2019;13(1):92-103.

27. Bunse C, Koch H, Breider S, Simon M, Wietz M. Sweet spheres: succession and CAZyme expression of marine bacterial communities colonizing a mix of alginate and pectin particles. Environ Microbiol. 2021;23(6):3130-48.

28. Kang S, Kim JK yu. Reuse of red seaweed waste by a novel bacterium, Bacillus sp. SYR4 isolated from a sandbar. World J Microbiol Biotechnol. 2015;31:209-17.

29. Jonnadula R, Verma P, Shouche YS, Ghadi SC. Characterization of Microbulbifer strain CMC-5, a new biochemical variant of Microbulbifer elongatus type strain DSM6810 ${ }^{\mathrm{T}}$ isolated from decomposing seaweeds. Curr Microbiol. 2009;59:600-7. 
558 30. Hehemann JH, Arevalo P, Datta MS, Yu X, Corzett CH, Henschel A, et al. Adaptive

559 radiation by waves of gene transfer leads to fine-scale resource partitioning in marine

560 microbes. Nat Commun. 2016;7:12860.

561 31. Gralka M, Szabo R, Stocker R, Cordero OX. Trophic interactions and the drivers of 562 microbial community assembly. Curr Biol. 2020;30(19):R1176-88.

563 32. Martin M, Barbeyron T, Martin R, Portetelle D, Michel G, Vandenbol M. The cultivable surface microbiota of the brown alga Ascophyllum nodosum is enriched in macroalgal-polysaccharide-degrading bacteria. Front Microbiol. 2015;6:1487.

33. Dogs M, Wemheuer B, Wolter L, Bergen N, Daniel R, Simon M, et al.

35. Barbeyron T, L'Haridon S, Corre E, Kloareg B, Potin P. Zobellia galactanovorans gen.

34. Brunet M, Le Duff N, Fuchs B, Amann R, Barbeyron T, Thomas F. Specific detection and quantification of the marine flavobacterial genus Zobellia on macroalgae using novel qPCR and CARD-FISH assays. Syst Appl Microbiol. 2021;44(6):126269.

36. Barbeyron T, Thiébaud M, Le Duff N, Martin M, Corre E, Tanguy G, et al. Zobellia roscoffensis sp. nov. and Zobellia nedashkovskayae sp. nov., two flavobacteria from nov., sp. nov., a marine species of Flavobacteriaceae isolated from a red alga, and classification of [Cytophaga] uliginosa (ZoBell and Upham 1944) Reichenbach 1989 as Zobellia uliginosa gen. nov., comb. nov. Int J Syst Evol Microbiol. 2001;51(3):98597. the epiphytic microbiota of the brown alga Ascophyllum nodosum, and emended 
description of the genus Zobellia. Int J Syst Evol Microbiol. 2021;71(8).

582

37. Nedashkovskaya OI, Suzuki M, Vancanneyt M, Cleenwerck I, Lysenko AM, Mikhailov V V., et al. Zobellia amurskyensis sp. nov., Zobellia laminariae sp. nov. and Zobellia russellii sp. nov., novel marine bacteria of the family Flavobacteriaceae. Int J Syst Evol Microbiol. 2004;54(5):1643-8.

38. Nedashkovskaya O, Otstavnykh N, Zhukova N, Guzev K, Chausova V, Tekutyeva L, et al. Zobellia barbeyronii sp. nov., a new member of the family Flavobacteriaceae, isolated from seaweed, and emended description of the species Z. amurskyensis, $Z$. laminariae, Z. russellii and Z. uliginosa. Diversity. 2021;13(11):520.

39. Barbeyron T, Thomas F, Barbe V, Teeling H, Schenowitz C, Dossat C, et al. Habitat and taxon as driving forces of carbohydrate catabolism in marine heterotrophic bacteria: Example of the model algae-associated bacterium Zobellia galactanivorans Dsij $^{\mathrm{T}}$. Environ Microbiol. 2016;18:4610-27.

40. Chernysheva N, Bystritskaya E, Stenkova A, Golovkin I. Comparative genomics and CAZyme genome repertoires of marine Zobellia amurskyensis KMM $3526^{\mathrm{T}}$ and Zobellia laminariae KMM $3676^{\mathrm{T}}$. 2019;17(12):661.

41. Chernysheva N, Bystritskaya E, Likhatskaya G, Nedashkovskaya O, Isaeva M. Genome-wide analysis of PL7 alginate lyases in the genus Zobellia. Molecules. $2021 ; 26(8): 2387$.

42. Potin P, Sanseau A, Le Gall Y, Rochas C, Kloareg B. Purification and characterization of a new k $\square$ carrageenase from a marine Cytophaga $\square$ like bacterium. Eur J Biochem. 1991;201(1):241-7.

43. Lami R, Grimaud R, Sanchez-Brosseau S, Six C, Thomas F, West NJ, et al. Marine 
bacterial models for experimental biology. In: Boutet A, Schierwater B, editors. Handbook of Marine Model Organisms in Experimental Biology. 2021.

44. Dudek M, Dieudonné A, Jouanneau D, Rochat T, Michel G, Sarels B, et al. Regulation of alginate catabolism involves a GntR family repressor in the marine flavobacterium

45. Thomas F, Lundqvist LCE, Jam M, Jeudy A, Barbeyron T, Sandström C, et al. Zobellia galactanivorans Dsij ${ }^{\mathrm{T}}$. Nucleic Acids Res. 2020;48(14):7786-800.

46. Thomas F, Barbeyron T, Tonon T, Génicot S, Czjzek M, Michel G. Characterization of Comparative characterization of two marine alginate lyases from Zobellia galactanivorans reveals distinct modes of action and exquisite adaptation to their natural substrate. J Biol Chem. 2013;288(32):23021-37.

47. Jam M, Flament D, Allouch J, Potin P, Thion L, Kloareg B, et al. The endo- $\beta$-agarases AgaA and AgaB from the marine bacterium Zobellia galactanivorans: Two paralogue 
degradation of algal laminarin. J Biol Chem. 2014;289(4):2027-42.

628

50. Labourel A, Jam M, Legentil L, Sylla B, Hehemann JH, Ferrières V, et al. Structural and biochemical characterization of the laminarinase ZgLamCGH16 from Zobellia galactanivorans suggests preferred recognition of branched laminarin. Acta Crystallogr. 2015;D71:173-84.

51. Dorival J, Ruppert S, Gunnoo M, Orłowski A, Chapelais-Baron M, Dabin J, et al. The laterally-acquired GH5 ZgEngAGH5_4 from the marine bacterium Zobellia galactanivorans is dedicated to hemicellulose hydrolysis. Biochem $\mathrm{J}$. 2018;475(22):3609-28.

52. Groisillier A, Labourel A, Michel G, Tonon T. The mannitol utilization system of the marine bacterium Zobellia galactanivorans. Appl Environ Microbiol. 2015;81(5):1799-812.

53. Fournier JB, Rebuffet E, Delage L, Grijol R, Meslet-Cladière L, Rzonca J, et al. The vanadium iodoperoxidase from the marine Flavobacteriaceae species Zobellia galactanivorans reveals novel molecular and evolutionary features of halide specificity in the vanadium haloperoxidase enzyme family. Appl Environ Microbiol. 2014;80(24):7561-73.

54. Grigorian E, Groisillier A, Thomas F, Leblanc C, Delage L. Functional characterization of a L-2-haloacid dehalogenase from Zobellia galactanivorans Dsij $^{\mathrm{T}}$ suggests a role in haloacetic acid catabolism and a wide distribution in marine environments. Front Microbiol. 2021;12:725997.

55. Zhu Y, Thomas F, Larocque R, Li N, Duffieux D, Cladière L, et al. Genetic analyses unravel the crucial role of a horizontally acquired alginate lyase for brown algal 
biomass degradation by Zobellia galactanivorans. Environ Microbiol. 2017;19(6):2164-81.

56. Zablackis E, Perez J. A partially pyruvated carrageenan from hawaiian Grateloupia filicina (Cryptonemiales, Rhodophyta). Bot Mar. 1990;33(3):273-6.

57. Filisetti-Cozzi T, Carpita N. Measurement of uronic acids without interference from neutral sugars. Anal Biochem. 1991;197(1):15162.

58. Blumenkrantz N, Asboe-Hansen G. New method for quantitative determination of uronic acids. Anal Biochem. 1973;54(2):484-9.

59. Cumashi A, Ushakova NA, Preobrazhenskaya ME, D’Incecco A, Piccoli A, Totani L, et al. A comparative study of the anti-inflammatory, anticoagulant, antiangiogenic, and antiadhesive activities of nine different fucoidans from brown seaweeds. Glycobiology. 2007; 17(5):541-52. aerobes. J Mar Res. 1941;4:75.

61. Klindworth A, Pruesse E, Schweer T, Peplies J, Quast C, Horn M, et al. Evaluation of general 16S ribosomal RNA gene PCR primers for classical and next-generation sequencing-based diversity studies. Nucleic Acids Res. 2013;41(1):e1.

62. Patro R, Duggal G, Love MI, Irizarry RA, Kingsford C. Salmon provides fast and biasaware quantification of transcript expression. Nat Methods. 2017;14(4):417-9.

63. Love MI, Huber W, Anders S. Moderated estimation of fold change and dispersion for RNA-seq data with DESeq2. Genome Biol. 2014;15(12):1-21. 
Austria: R Foundation for Statistical Computing; 2018.

673

65. Lex A, Gehlenborg N, Strobelt H. UpSet: Visualization of intersecting sets. IEEE Trans Vis Comput Graph. 2014;20(12):1983-92.

66. Krassowski M. krassowski/complex-upset. 2020.

67. Murtagh F, Legendre P. Ward's hierarchical clustering method: clustering criterion and agglomerative algorithm. J Classif. 2014;31:274-95.

68. Wickham H. Use R! ggplot2: Elegant graphics for data analysis. Second Edition. 2016.

69. Kidby DK, Davidson DJ. Ferricyanide estimation of sugars in the nanomole range. Anal Biochem. 1973;55:321-5.

70. Zhang H, Yohe T, Huang L, Entwistle S, Wu P, Yang Z, et al. DbCAN2: A meta server for automated carbohydrate-active enzyme annotation. Nucleic Acids Res. 2018;46(W1):W95-101.

71. Chen X, Hu Y, Yang B, Gong X, Zhang N, Niu L, et al. Structure of lpg0406, a carboxymuconolactone decarboxylase family protein possibly involved in antioxidative response from Legionella pneumophila. Protein Sci. 2015;24(12):2070-5.

72. Handa N, Terada T, Doi-katayama Y, HIrota H, Tame J, Park A, et al. Crystal structure of a novel polyisoprenoid-binding protein from Thermus thermophilus HB8. Protein Sci. 2005;14(4):1004-10.

73. Weber A, Kögl SA, Jung K. Time-dependent proteome alterations under osmotic stress during aerobic and anaerobic growth in Escherichia coli. J Bacteriol. 2006;188(20):7165-75.

74. Enke TN, Datta MS, Schwartzman J, Cermak N, Schmitz D, Barrere J, et al. Modular 
assembly of polysaccharide-degrading marine microbial communities. Curr Biol. 2019;29(9):1528-1535.e6.

75. Pollak S, Gralka M, Sato Y, Schwartzman J, Lu L, Cordero OX. Public good exploitation in natural bacterioplankton communities. Sci Adv. 2021;7:eabi4717.

698

699

76. Pontrelli S, Szabo R, Pollak S, Schwartzman J, Ledezma D, Cordero OX, et al. Hierarchical control of microbial community assembly. bioRxiv [Internet]. 2021; Available from: https://doi.org/10.1101/2021.06.22.449372

77. Holdt SL, Kraan S. Bioactive compounds in seaweed: Functional food applications and legislation. J Appl Phycol. 2011;23(3):543-97.

78. Kawamura-Konishi Y, Watanabe N, Saito M, Nakajima N, Sakaki T, Katayama T, et al. Isolation of a new phlorotannin, a potent inhibitor of carbohydrate-hydrolyzing enzymes, from the brown alga Sargassum patens. J Agric Food Chem. 2012;60(22):5565-70.

79. Garbary DJ, Brown NE, MacDonell HJ, Toxopeux J. Ascophyllum and its symbionts - A complex symbiotic community on North Atlantic shores. In: Algal and Cyanobacteria Symbioses. 2017. p. 547-72.

80. Pluvinage B, Grondin JM, Amundsen C, Klassen L, Moote PE, Xiao Y, et al. Molecular basis of an agarose metabolic pathway acquired by a human intestinal symbiont. Nat Commun. 2018;9:1043.

81. Reintjes G, Arnosti C, Fuchs BM, Amann R. An alternative polysaccharide uptake mechanism of marine bacteria. ISME J. 2017;11(7):1640-50.

82. Mabeau S, Kloareg B, Joseleau J-P. Fractionation and analysis of fucans from brown 
algae. Phytochemistry. 1990;29(8):2441-5.

83. Küpper FC, Kloareg B, Guern J, Potin P. Oligoguluronates elicit an oxidative burst in the brown algal kelp Laminaria digitata. Plant Physiol. 2001;125(1):278-91.

84. Küpper FC, Müller DG, Peters AF, Kloareg B, Potin P. Oligoalginate recognition and oxidative burst play a key role in natural and induced resistance of sporophytes of Laminariales. Ann Oper Res. 2002;28(10):2057-81.

85. Sato K, Naito M, Yukitake H, Hirakawa H, Shoji M, McBride MJ, et al. A protein secretion system linked to bacteroidete gliding motility and pathogenesis. PNAS. 2010;107(1):276-81.

86. Eckroat TJ, Greguske C, Hunnicutt DW. The type 9 secretion system is required for Flavobacterium johnsoniae biofilm formation. Front Microbiol. 2021;12:660887.

87. Xie S, Tan Y, Song W, Zhang W, Qi Q, Lu X. N-glycosylation of a cargo protein Cterminal domain recognized by the type IX secretion system in Cytophaga hutchinsonii affects protein secretion and localization. Appl Environ Microbiol. 2021. 


\section{Figure legends}

733 Figure 1: Ability of Z. galactanivorans Dsij $^{\mathrm{T}}$ to use fresh brown macroalgae for its

734 growth. (A) Growth of Z. galactanivorans with either macroalgae pieces (Laminaria digitata,

735 Fucus serratus and Ascophyllum nodosum) or purified sugars (maltose, alginate and FCSPs).

736 Individual points for replicate experiments are shown. Lines are means of independent

737 replicates $(\mathrm{n}=2$ or $\mathrm{n}=3$ ). (B) Photographs showing the integrity of the L. digitata tissues

738 after 65 h. (C) L. digitata tissues colonization by Z. galactanivorans during the degradation.

739 Micrographs are overlay of the CARD-FISH signal (magenta, Zobellia-specific probe with

740 Alexa488 as the reporter signal) and the algal autofluorescence (green) and were obtained

741 with the surface channel mode of the $3 \mathrm{D}$ viewer. For the different times, transversal views are

742 shown on the left and top views on the right. The non-fluorescent gap between the bacterial

743 cells and the algal cells likely represent the mucilage coat of L. digitata. The absence of algal

744 autofluorescence signal below $25-30 \mu \mathrm{m}$ is the result of its rapid decrease in intensity as we

745 move away from the coverslip.

746 Figure 2: General features of the transcriptomic responses occurring in free-living $Z$.

747 galactanivorans Dsij $^{\mathbf{T}}$ during growth with macroalgae. (A) Principal Component Analysis

748 of the gene expression. (B) Upset plot of the differentially expressed genes with maltose as

749 the control condition (Bonferroni-adjusted p-value $<0.05$ and $|\log 2 \mathrm{FC}|>2$ ). Set size

750 represents the total amount of genes regulated in each condition.

Figure 3: Regulation of the catabolic pathways during the degradation of fresh algal

tissues. (A) Heatmap of the 51 PULs identified in the genome of Z. galactanivorans Dsij $^{\mathrm{T}}$.

754 PUL 1 to 50 were identified during the annotation of the Z. galactanivorans Dsij $^{\mathrm{T}}$ genome by

755 the presence of the susCD-like pair (Supplementary Table S3 in (39)). PUL51 targeting 3,6-

756 anhydro-D-galactose and involved in carrageenan catabolism (but lacking the susCD-like 
757 pair) was further described (25). For each PUL, the mean $\log 2 \mathrm{FC}$ of all genes is represented,

758 taking maltose as a control condition. Carbon sources and PULs were arranged according to a 759 hierarchical clustering analysis (Ward's method). A PUL was considered regulated (induced 760 in red, repressed in blue) if more than $50 \%$ of the genes were significantly differentially 761 expressed (*) and strongly regulated if more than $80 \%$ of the genes were significantly 762 differentially expressed $(* *)$. Putative substrates targeted by the PULs are indicated. Hash 763 signs denote PULs biochemically characterized previously in Z. galactanivorans (\#\#) or in 764 another organism (\#). (B) Heatmap representing the $\log 2 \mathrm{FC}$ of individual genes contained in 765 the PULs induced with macroalgae and which clustered together in A. (C) Activity of 766 extracellular polysaccharidases secreted in the microcosms containing macroalgae. The mean 767 value measured in the uninoculated controls was subtracted from each value. Bars are means 768 of independent replicates $(n=2$ or 3 ) shown as individual points. Significant difference from 769 zero was tested when $\mathrm{n}=3$ (t-test; *, $\mathrm{P}<0.05)$. L. dig: Laminaria digitata; F. ser: Fucus 770 serratus; A. nod: Ascophyllum nodosum; FCSP: fucose containing sulfated polysaccharide; 771 PS: Polysaccharide.

Figure 4: Selection of genes specifically induced by fresh macroalgae. Mean expression

774 values $(\mathrm{n}=3$, except for $F$. serratus $\mathrm{n}=2)$ of selected genes significantly triggered $(*)$ with at 775 least one macroalgae compared to both the purified polysaccharides and maltose (see 776 SuppTable 4). No dot was represented if the mean read count was below 200. L. dig: 777 Laminaria digitata; F. ser: Fucus serratus; A. nod: Ascophyllum nodosum; Malt.: Maltose; 778 Algi.: Alginate; FCSP: fucose containing sulfated polysaccharide

780 Figure 5: Effect of the attachment to macroalgae during the degradation. (A) Number of 781 genes (Bonferroni-adjusted p-value < 0.05) up-regulated in algae-attached bacteria compared 
782 to free-living bacteria. The annotation of each gene is provided. (B) Alginolytic activity of the

783 enzymes secreted when Z. galactanivorans was grown in contact with L. digitata (black) or

784 separated from $L$. digitata by a $0.2 \mu \mathrm{m}$ filter (red). The activity was measured in each

785 compartment (left and right) and summed. Values are mean \pm s.d. $(\mathrm{n}=3)$.

Figure 6: Ability of Zobellia spp. to use fresh L. digitata for its growth. (A) Growth of eight Zobellia strains with $L$. digitata pieces (meristem of adult individuals). The generation time $t_{g e n}$ is indicated for each strain as well as the number of glycoside hydrolases $(\mathrm{GH}, \mathrm{blue})$, polysaccharides lyases (PL, yellow), carbohydrate esterases (CE, orange) and sulfatases (S, red) predicted in their genome (dbCAN search on the MaGe platform). Individual points for duplicate experiments are shown. Lines are means of independent replicates $(n=2$ or $n=3)$. (B) Comparison of genomic loci among the eight Zobellia strains. For Z. galactanivorans, genes were colored according to their expression $\log 2 \mathrm{FC}$ for the comparison L. digitata vs. maltose. Gene ID is indicated inside arrows and CAZymes and sulfatases are specified above. Top: genes involved in the alginate-utilization system. Bottom: genes contained in putative

797 FCSP PUL34 and 35. Zgal: Z. galactanivorans Dsij ${ }^{\text {T}}$; Zamu: Z. amurskyensis KMM $3526^{\text {T }}$; 


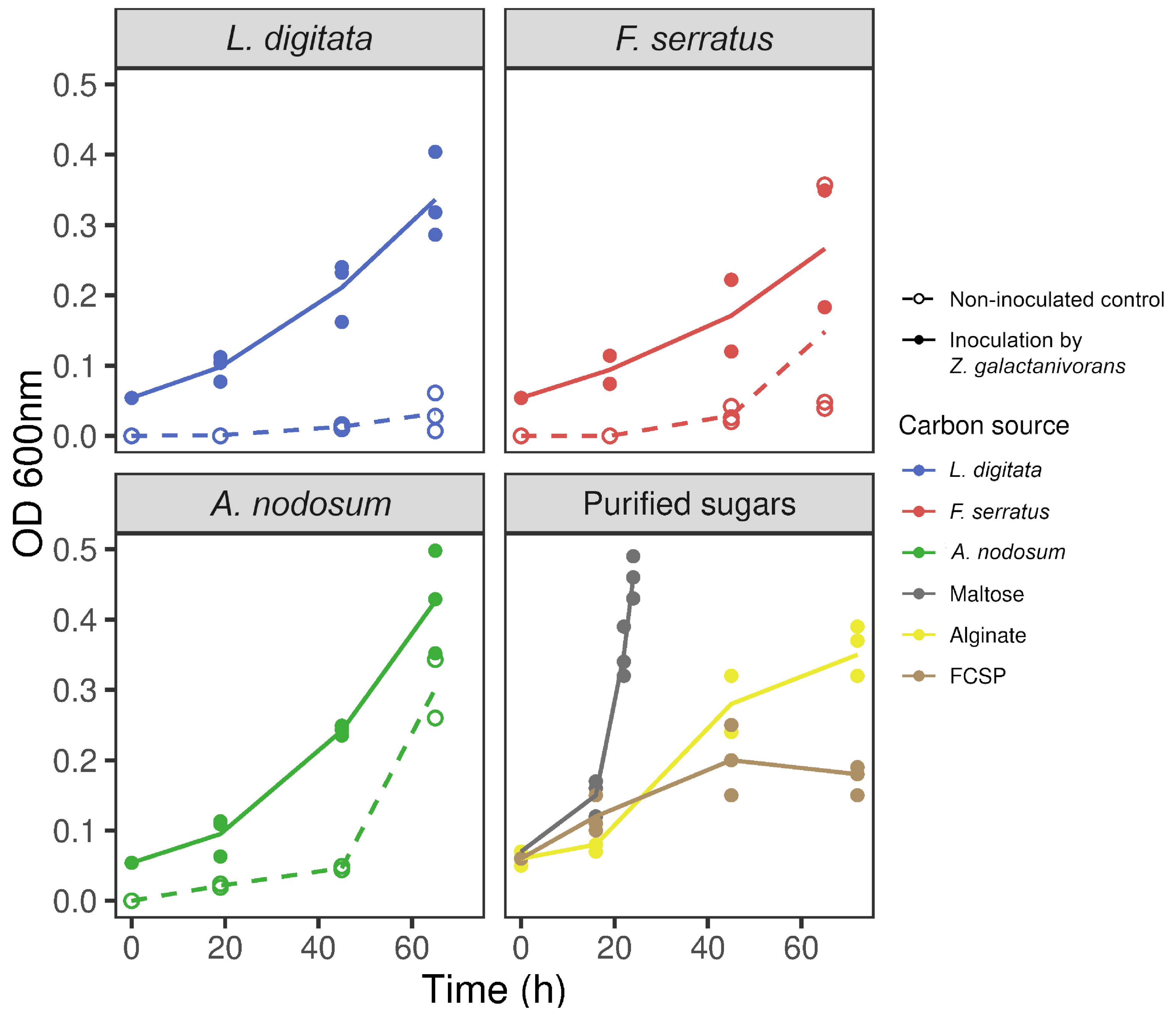

Non-inoculated control

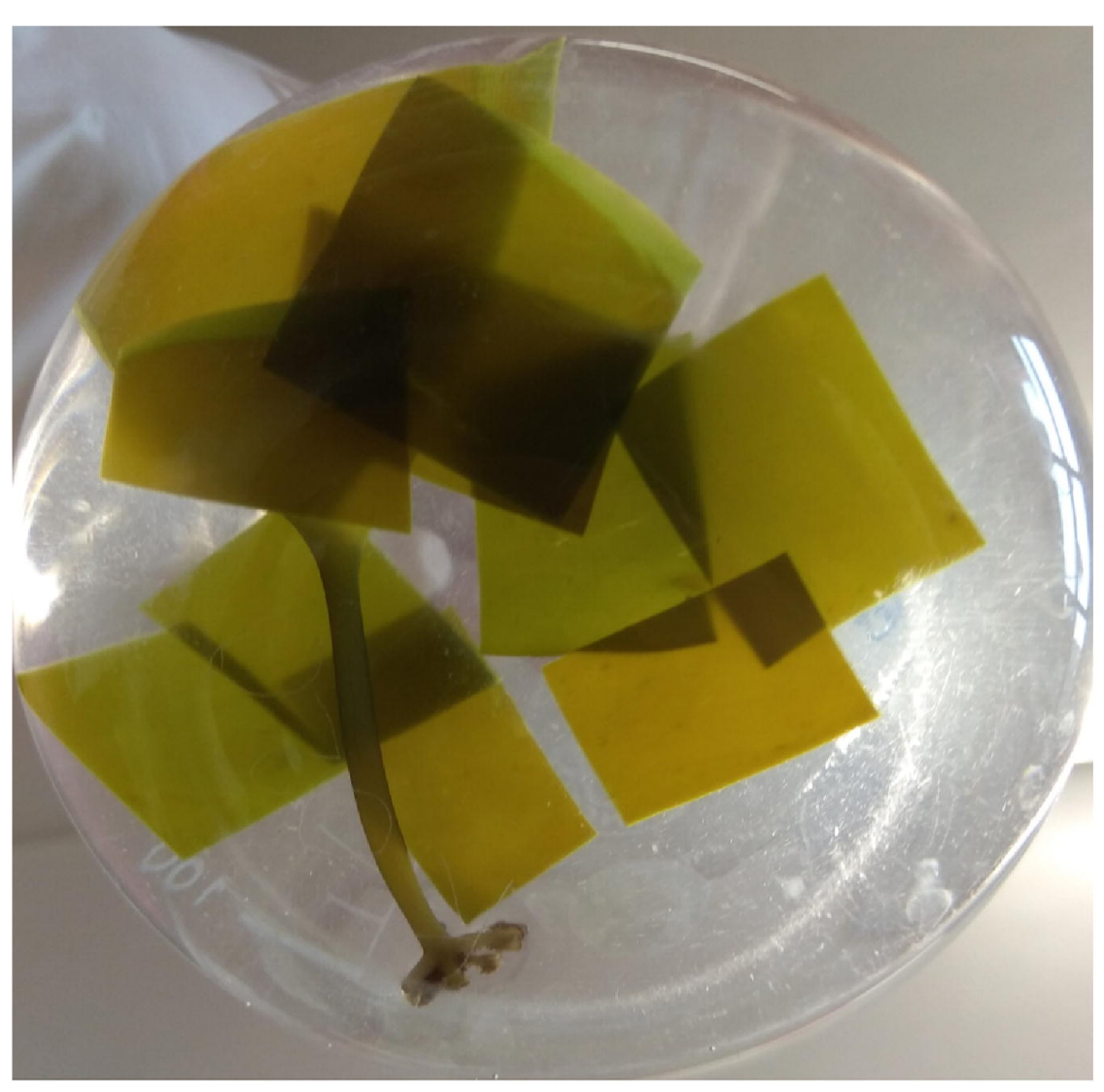

Inoculation by

Z. galactanivorans

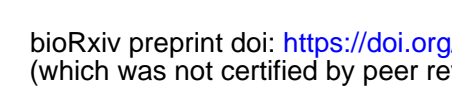

TO
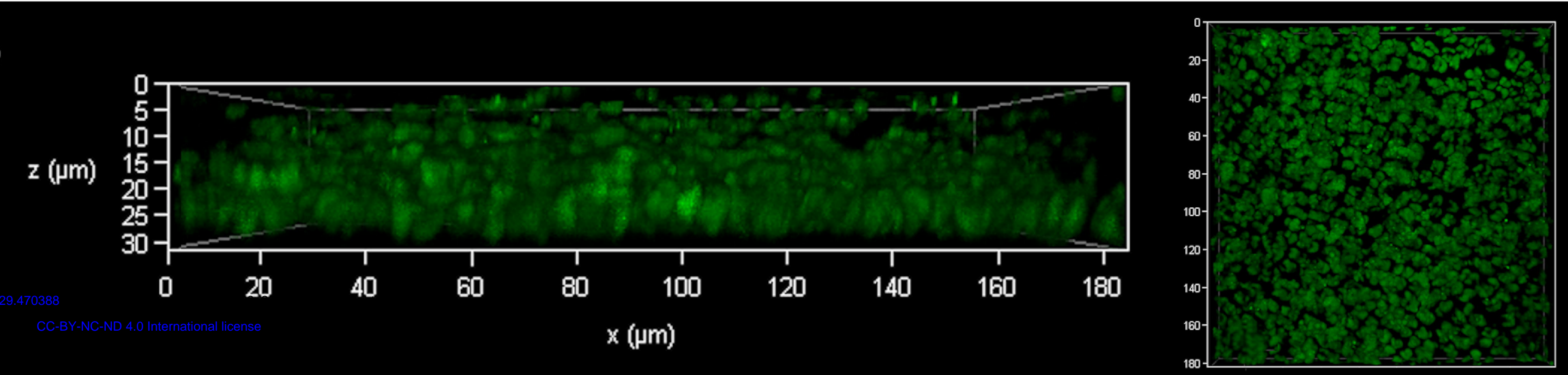

T22

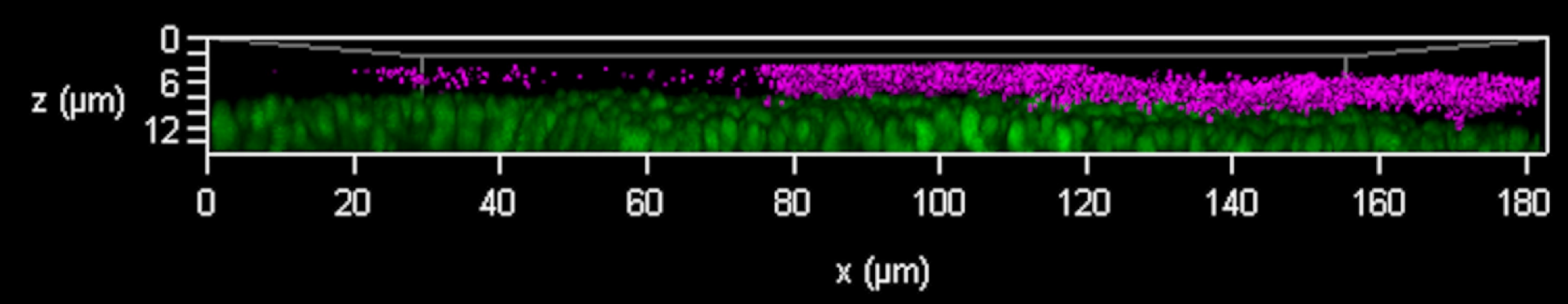

T46

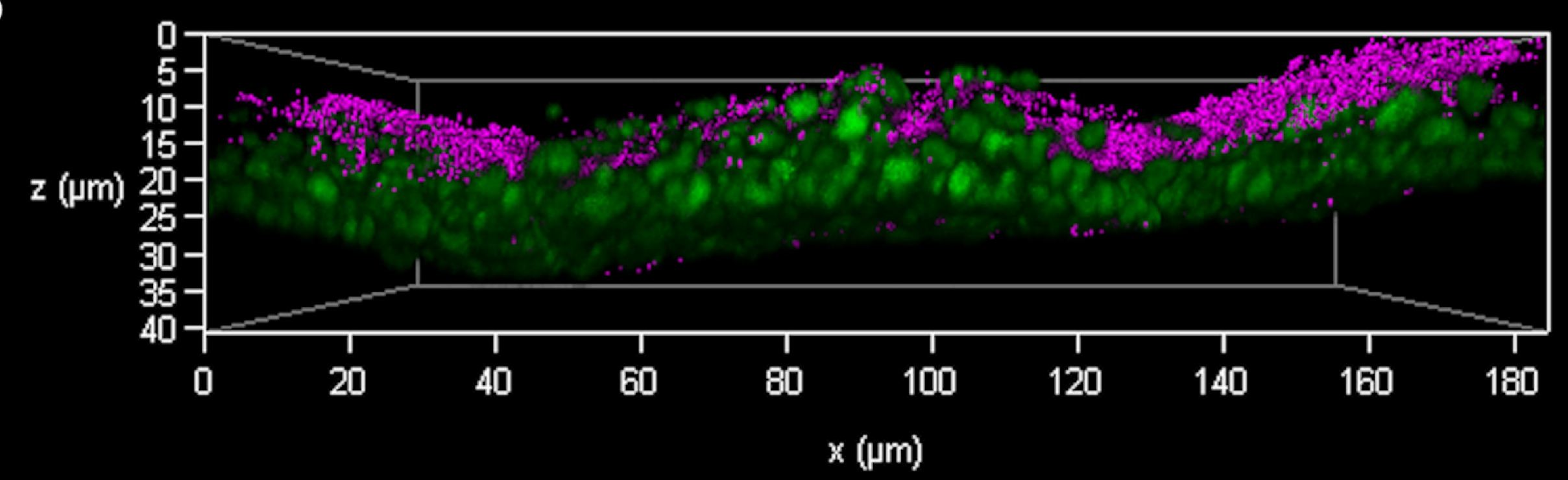

T70
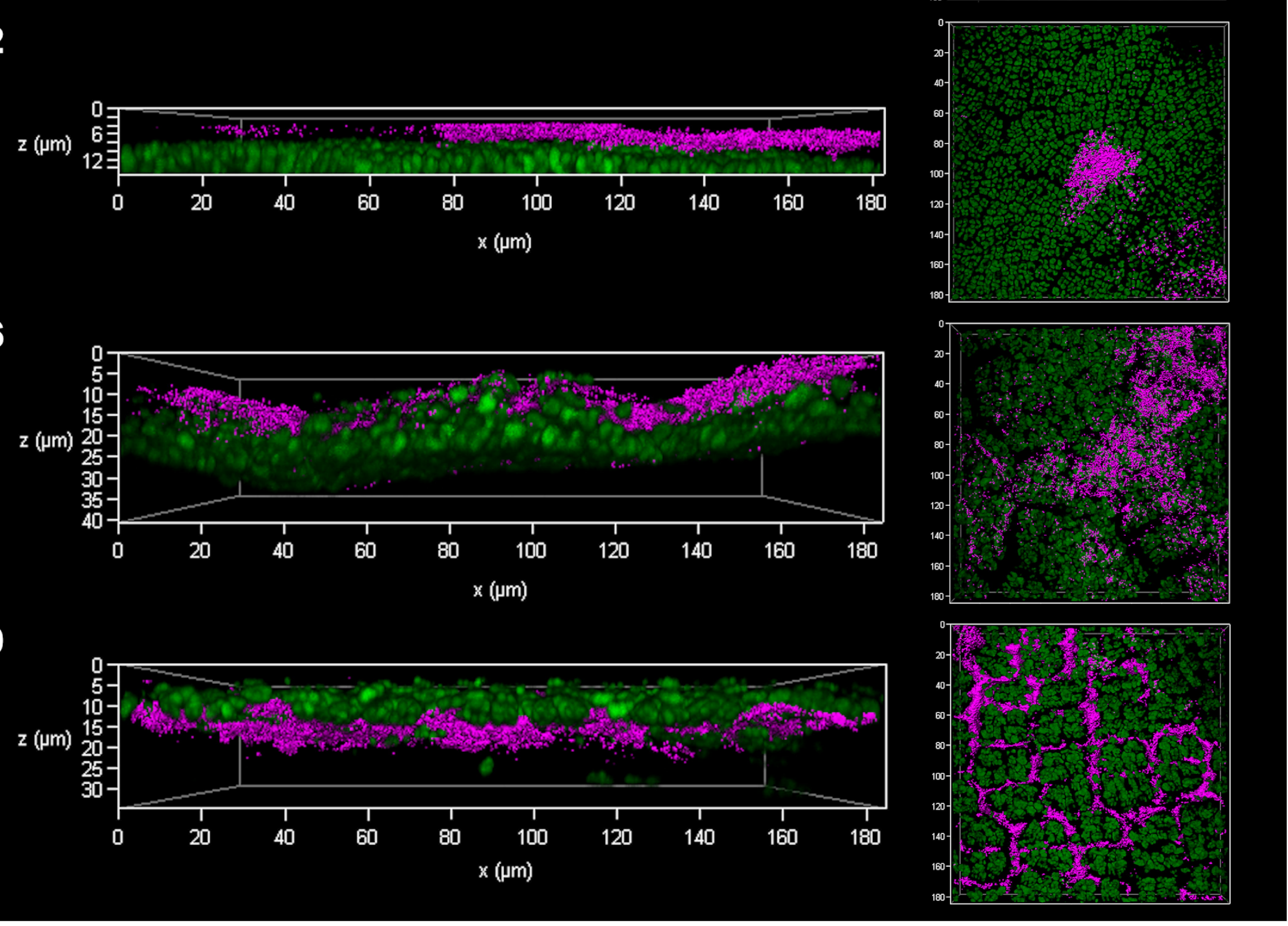
A

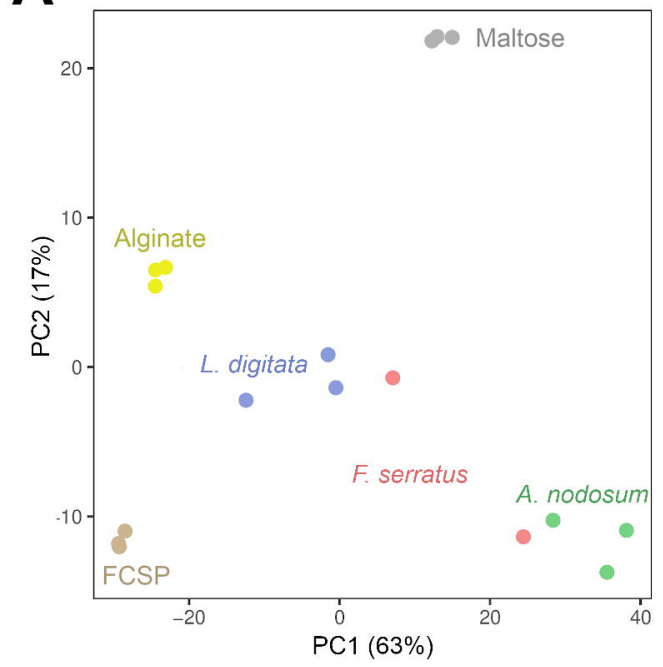

B

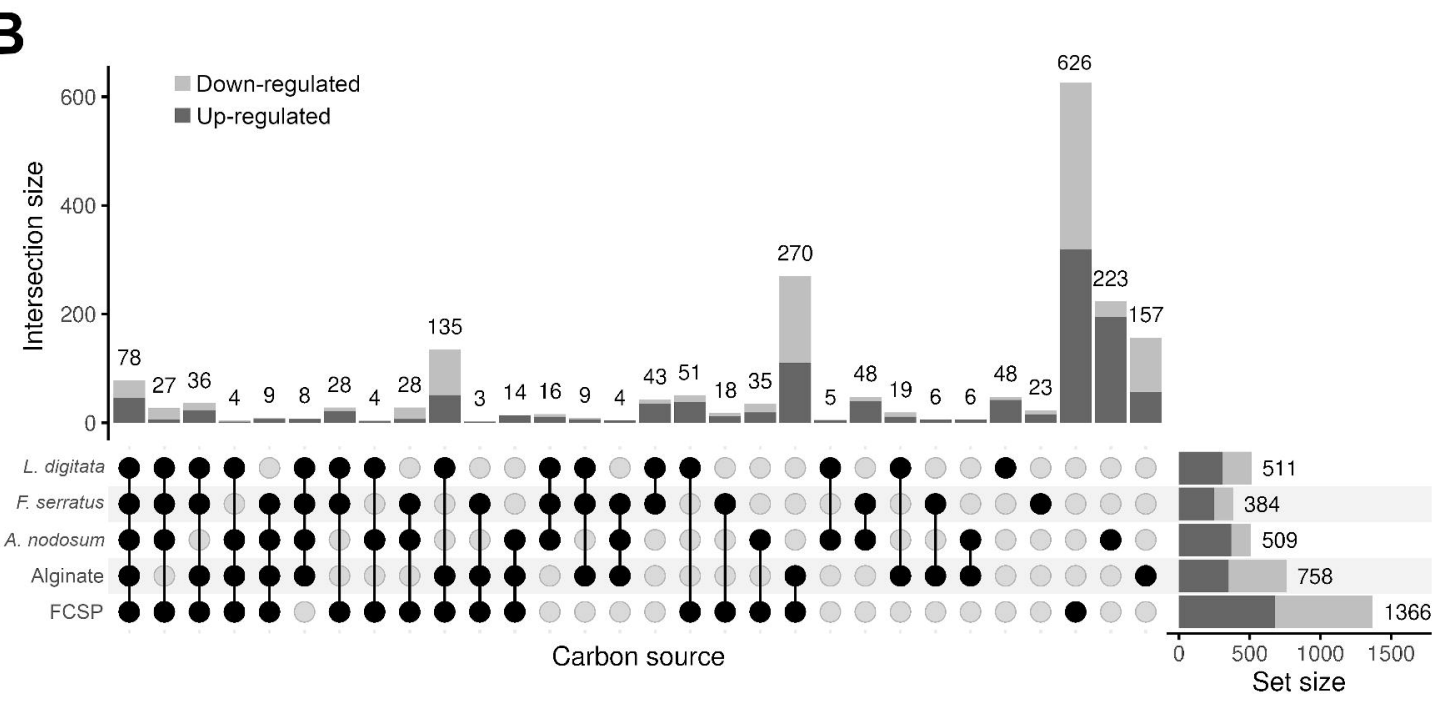

L. digitata 9999099909009909900090900000007511 A. nodosum Carbon source
100

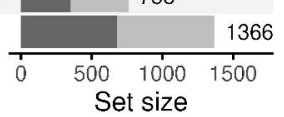



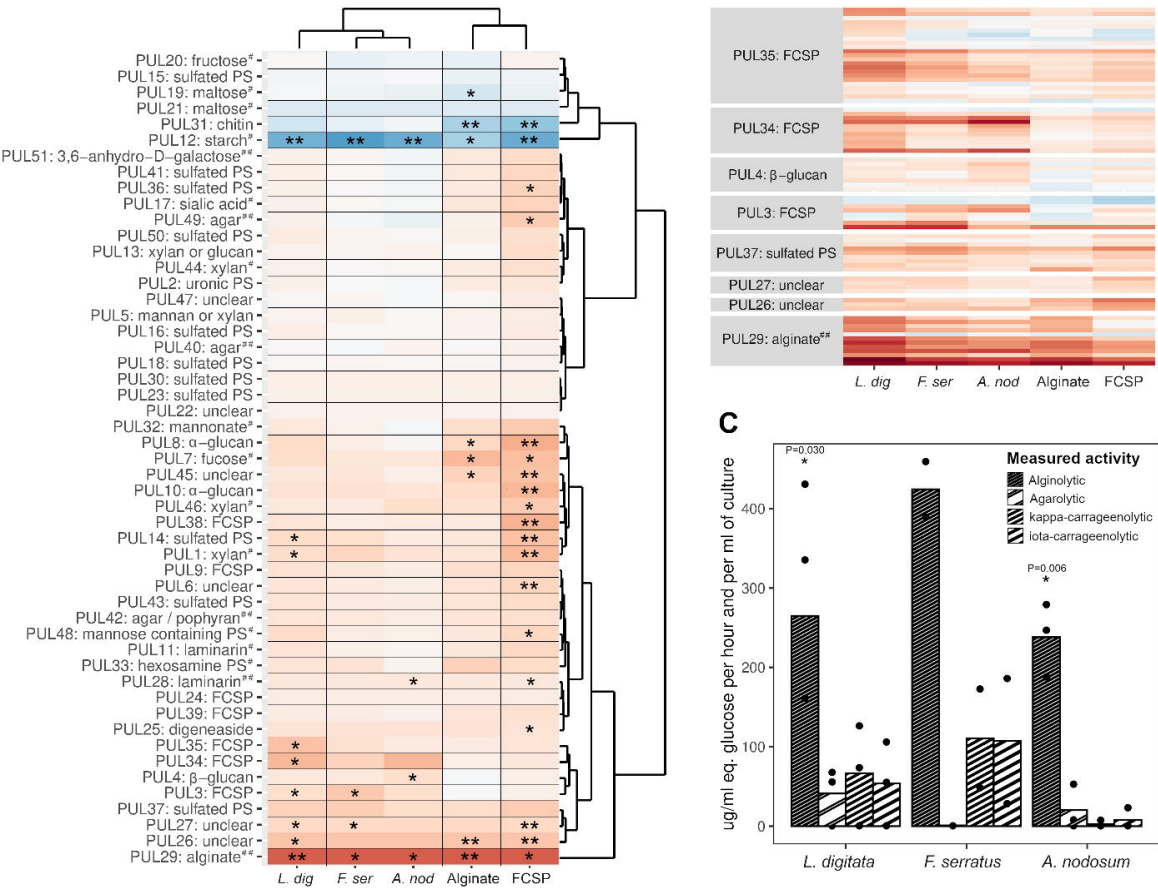

\section{C}

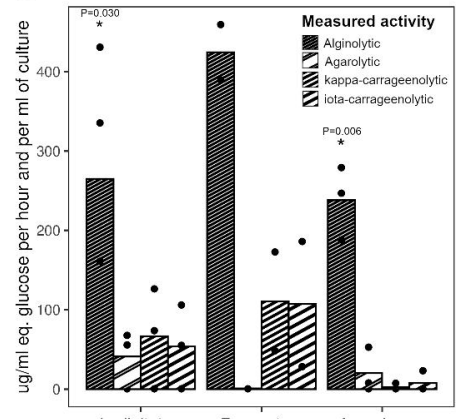

L. digitata

F. serratus

A. nodosum 


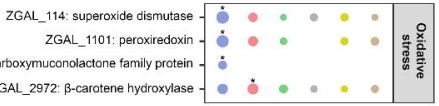

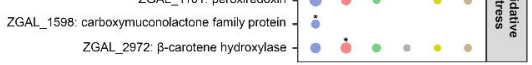

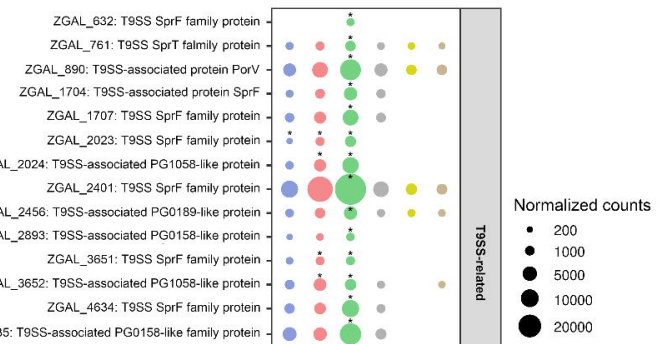
ZGAL_4635: T9SS-associated PG0158-like family protein ZGAL_2022: hypothetical protein with TIGR04131 CTD ZGAL_2761: hypothetical protein with TIGR04131 CTD ZGAL_2762: hypothetical protein with TIGR04131 CTD ZGAL_3727: hypothetical protein with TIGR04131 CTD ZGAL_93. hypothetical protein with TIGR04183 CTD ZGAL_1124: hypothetical prote in with TIGR04183 CTD ZGAL_4310: hypothetical protein with TIGR04183 CTD
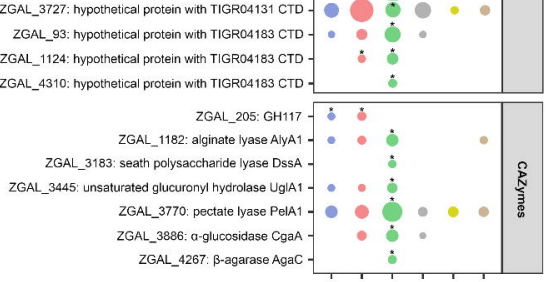

L. dig F.ser A.nod Malt Algi. FCSP 


\section{4 genes}

ZGAL_1162: chaperone GroL

ZGAL_1947: TetR-type transc. reg.

ZGAL_2823: chaperone GrpE

ZGAL_3427: unknown function

ZGAL_4232: TetR-type transc. reg.

ZGAL_4289: unknown function

ZGAL_4443: dehydrogenase/reductase

ZGAL_4453: Ycel family protein

ZGAL_4454: unknown function

ZGAL_4455: Ycel family protein

ZGAL_4708: chaperone DnaK

ZGAL_4745: chaperone CIpB1

ZGAL_607: chaperone HtpG

\section{F. serratus}

5 genes

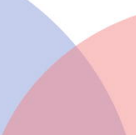

ZGAL_1365: iron-regulated protein A

ZGAL_1802: unknown function

ZGAL_1953: TBDR

ZGAL_1954: transc. metalloreg.

ZGAL_2856: unknown function

ZGAL_4250: quinone oxidoreductase

ZGAL_582: protein ArsC

ZGAL_857: TBDR

ZGAL_866: electron transfer flavoprotein

ZGAL_4237: small heat shock protein

ZGAL_4238: unknown function

ZGAL_4244: antibiotic biosynthesis monooxygenase family protein

ZGAL_4245: DNA protection during starvation protein

ZGAL_4246: aldo/keto reductase related to aryl-alcohol dehydrogenases

B

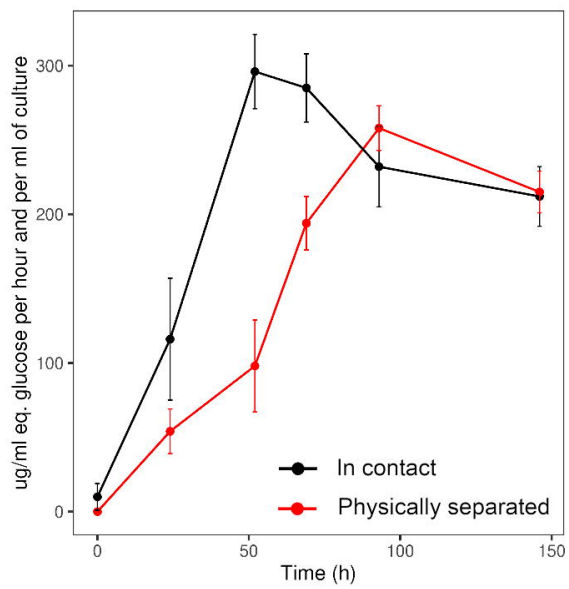

In contact
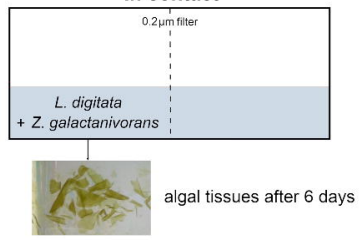

Physically separated
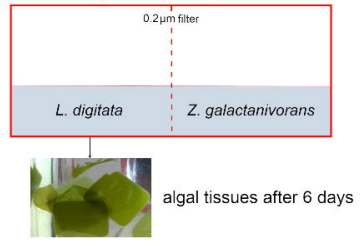

lime (n) 

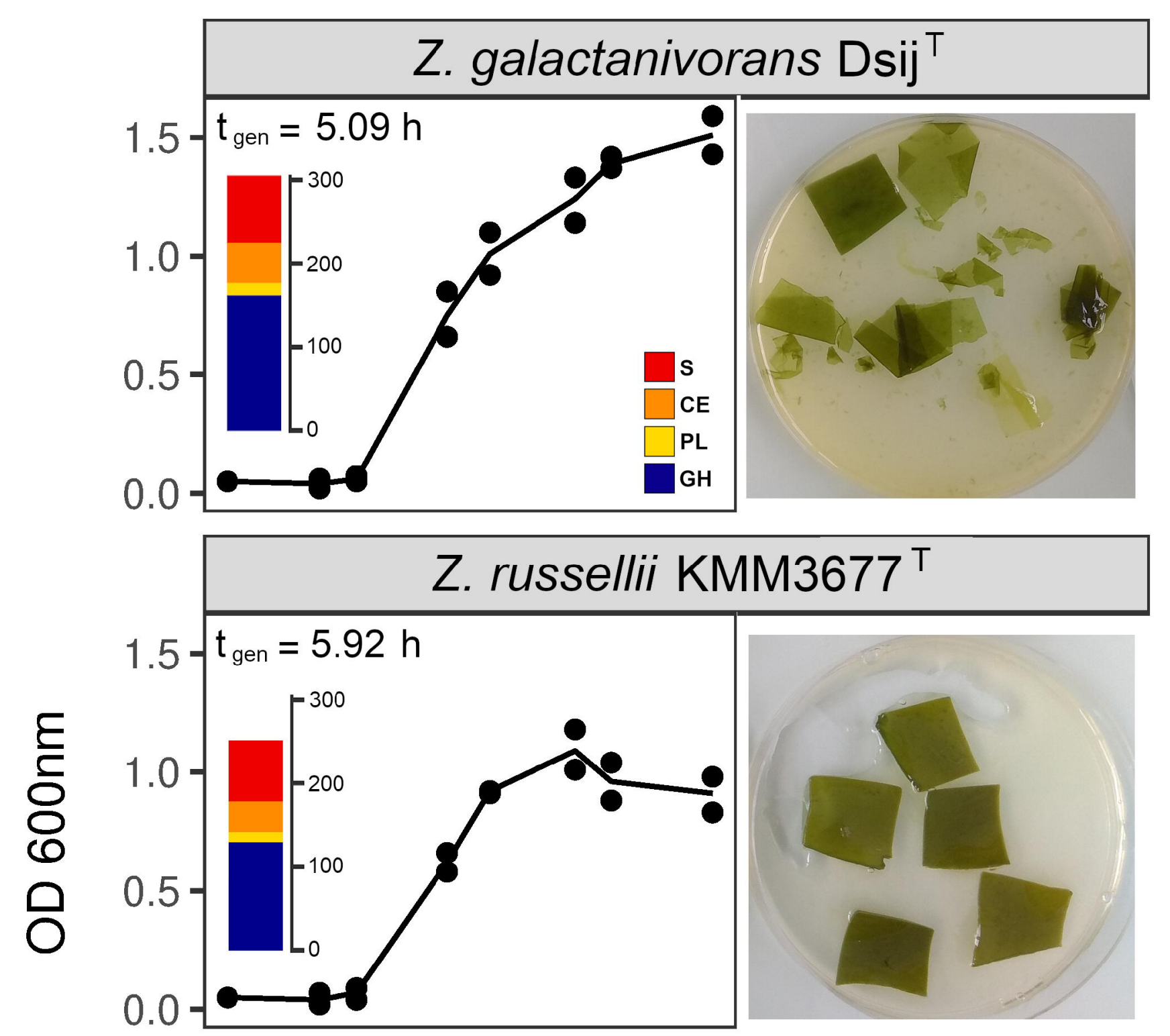

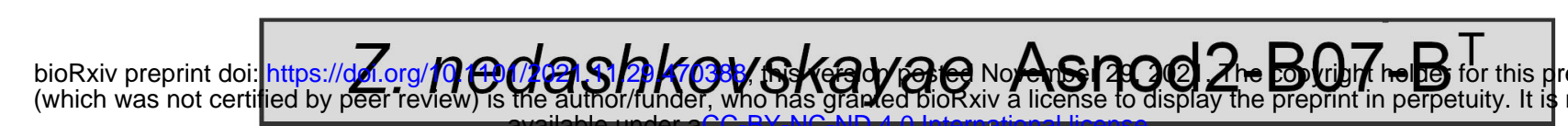

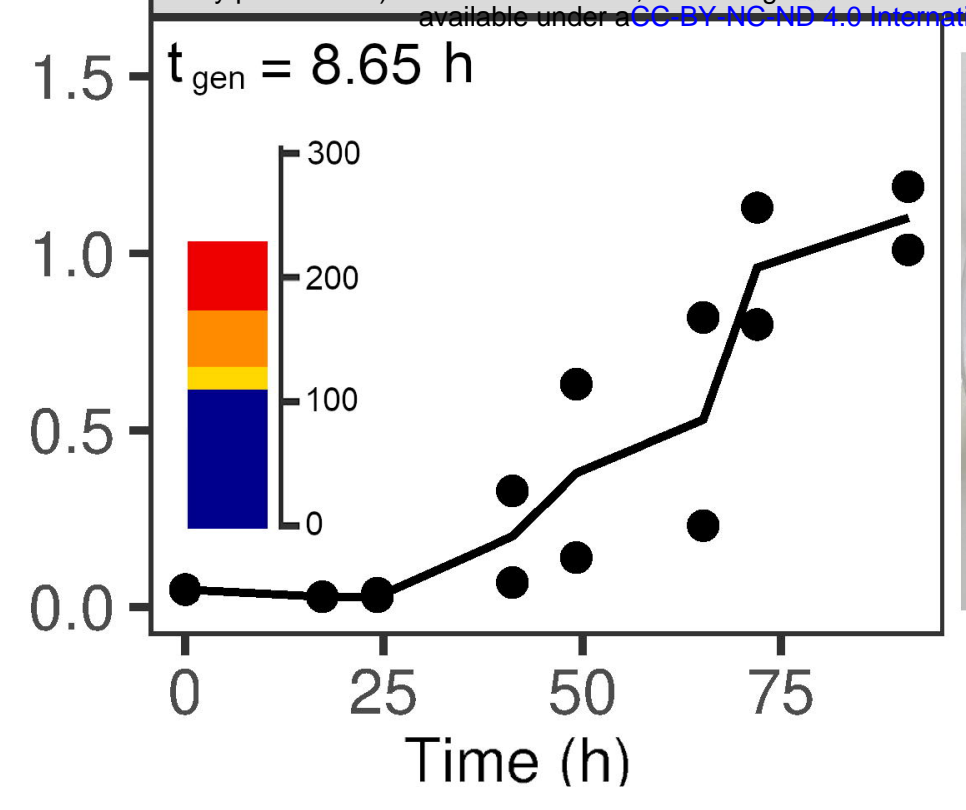

B

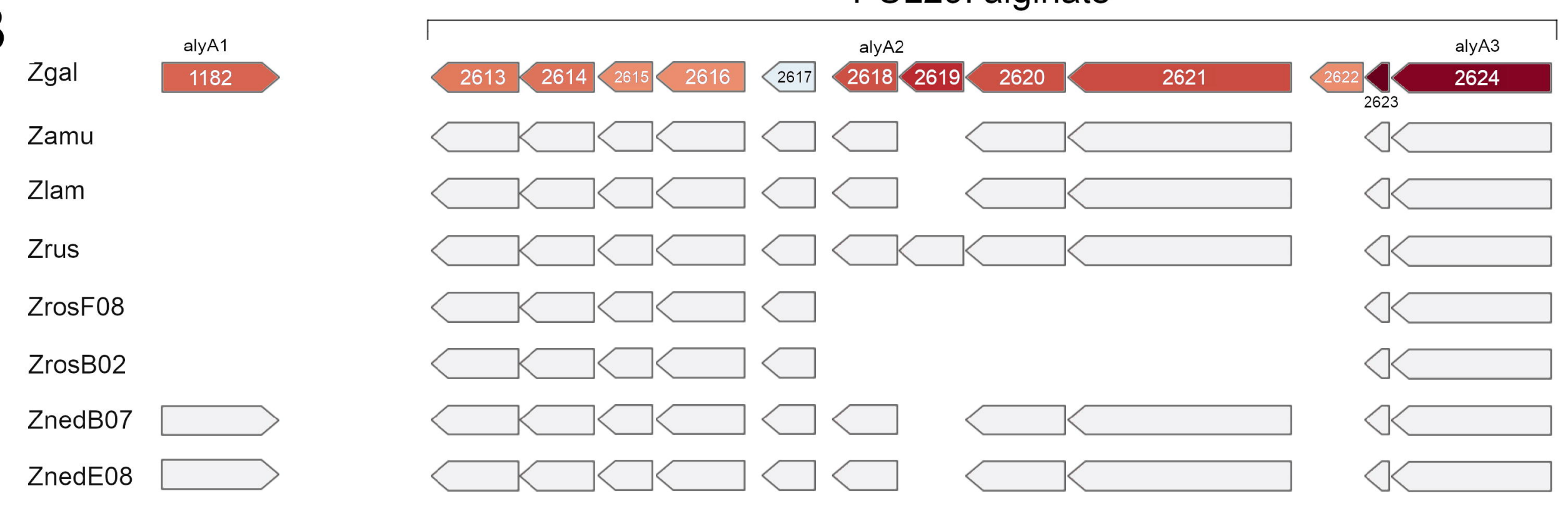

PUL34: FCSP

PUL29: alginate
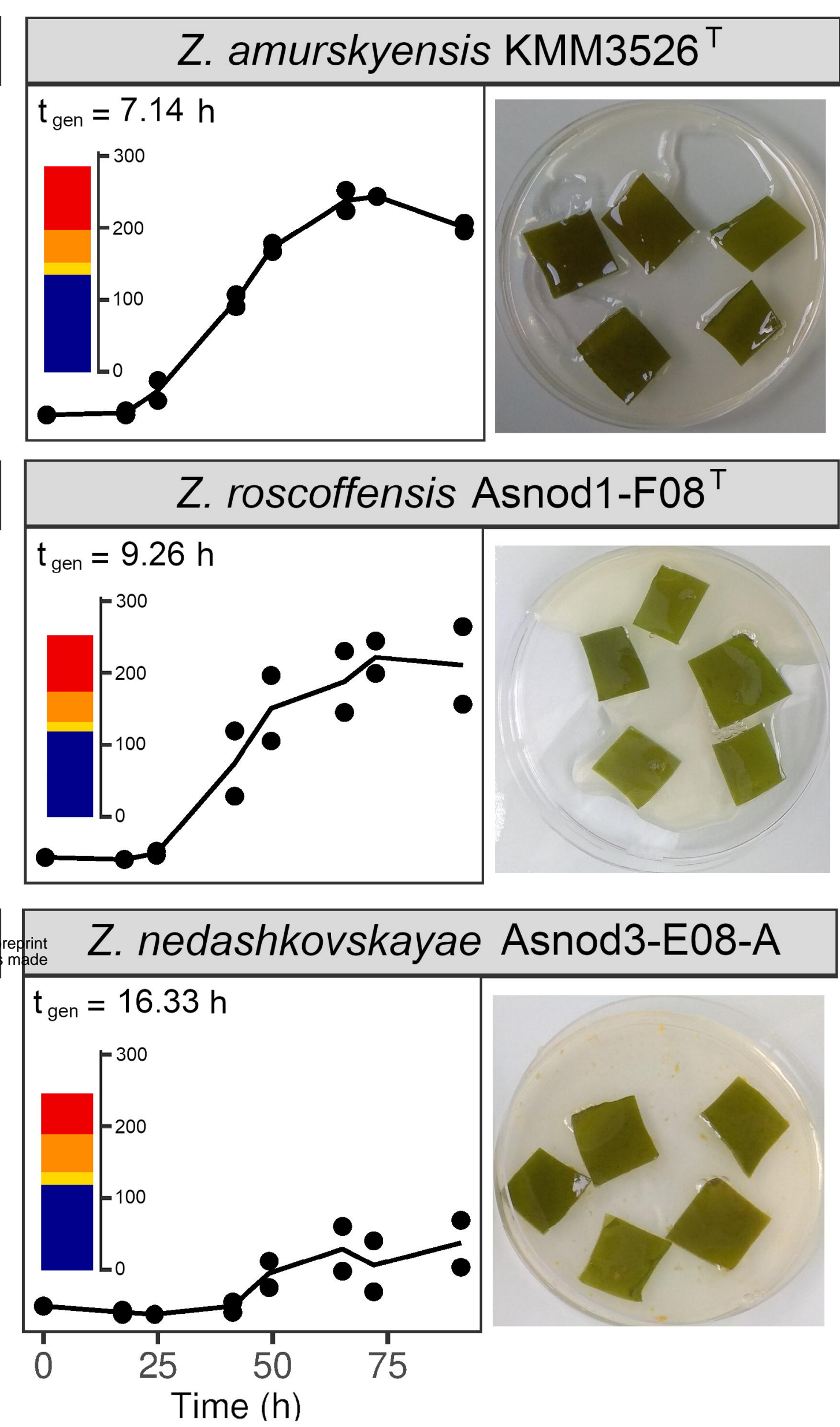

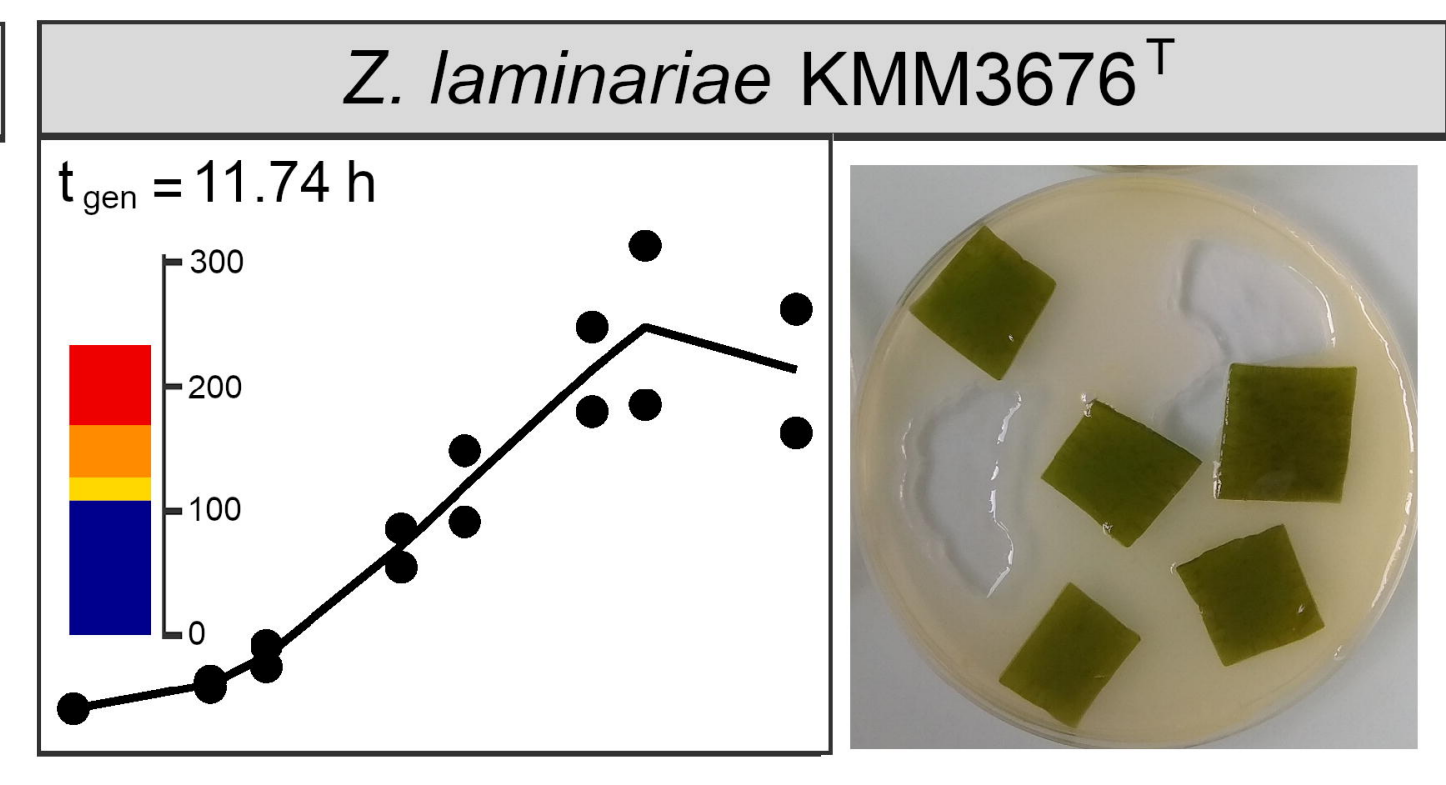

Z. roscoffensis Asnod2-B02-B

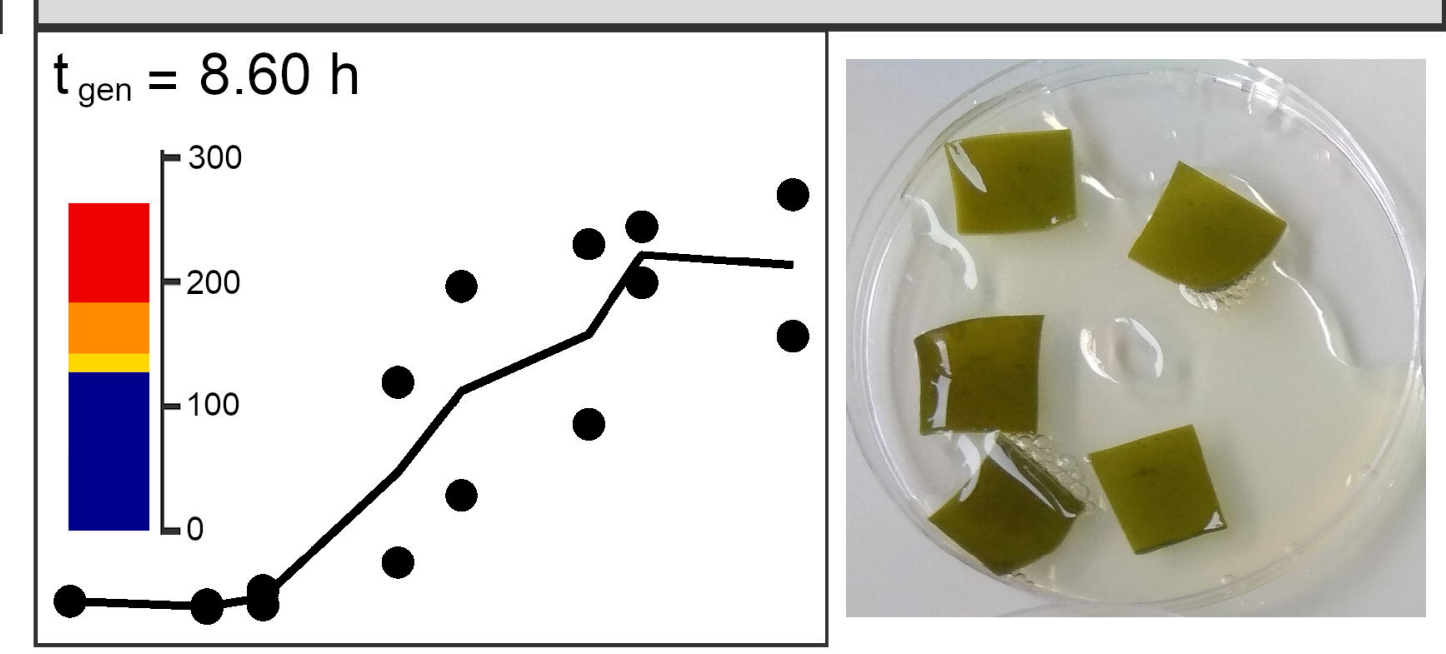

Non-inoculated control
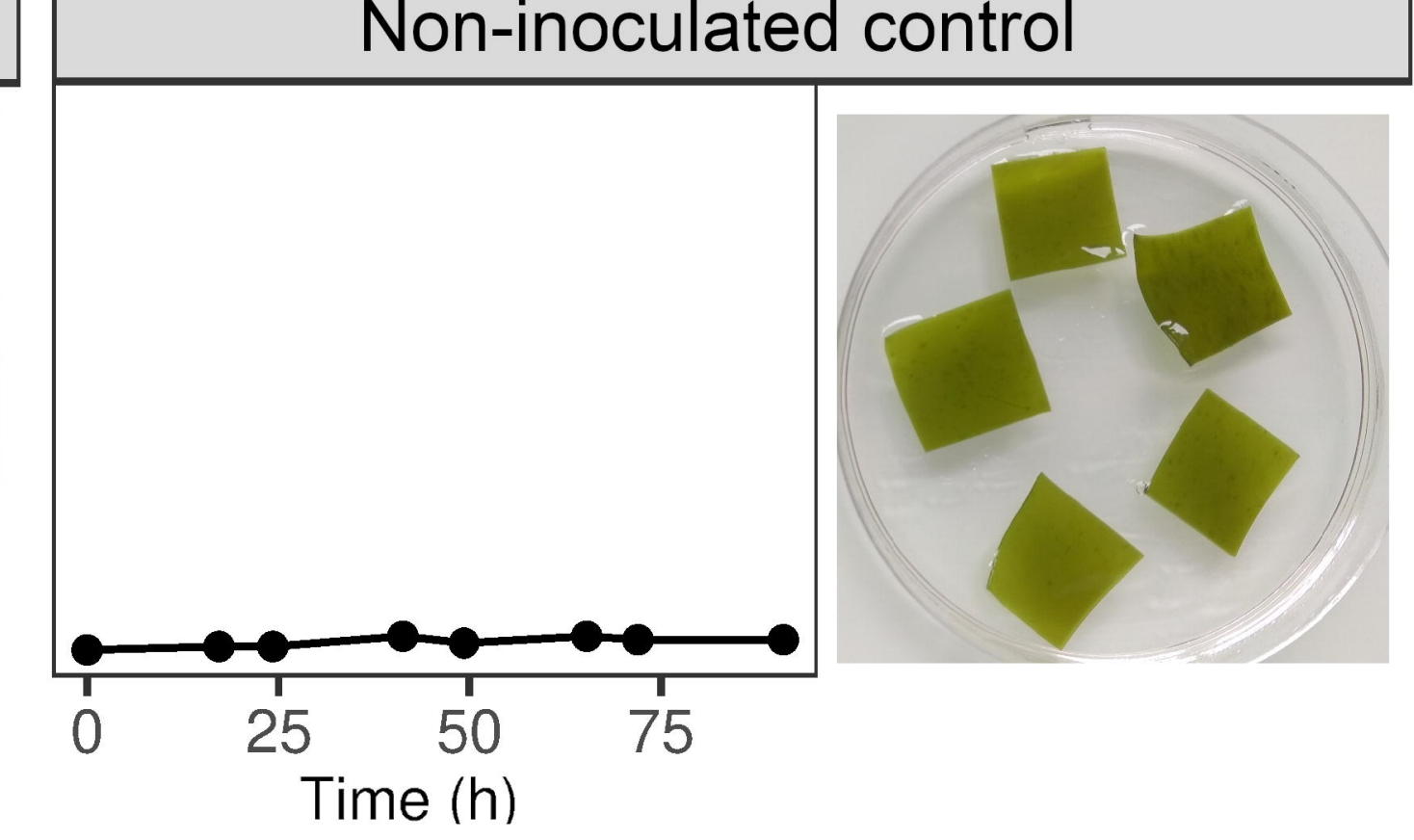

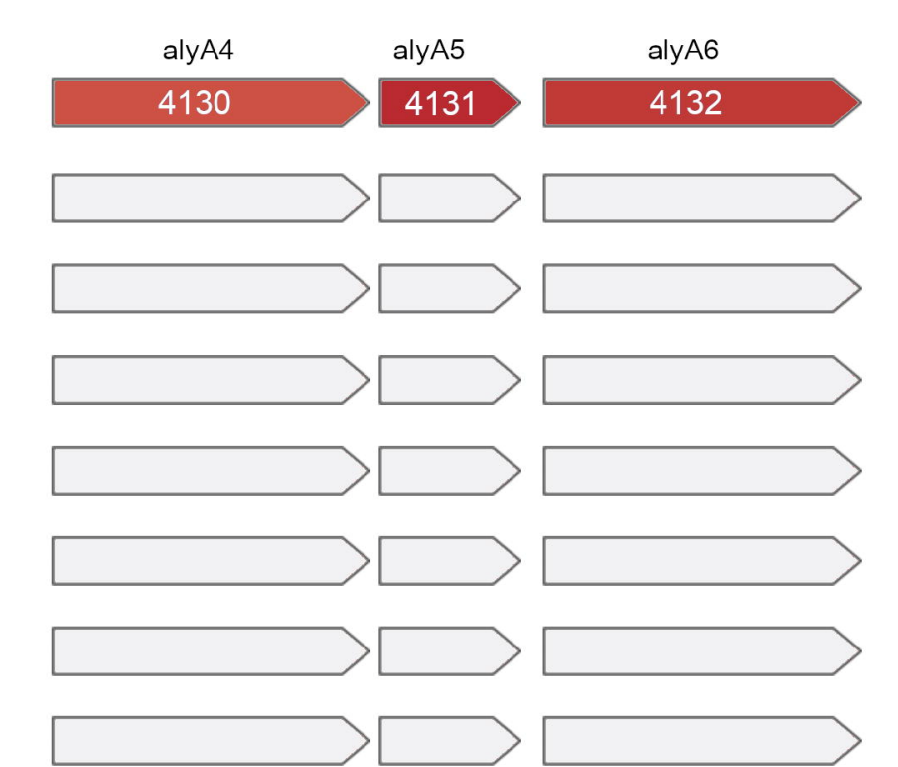

\begin{tabular}{ll} 
alyA7 \\
4327 \\
\hline
\end{tabular}

\section{PUL35: FCSP}

Log2 FoldChange $\begin{array}{lll}-4 & 0 & 4\end{array}$

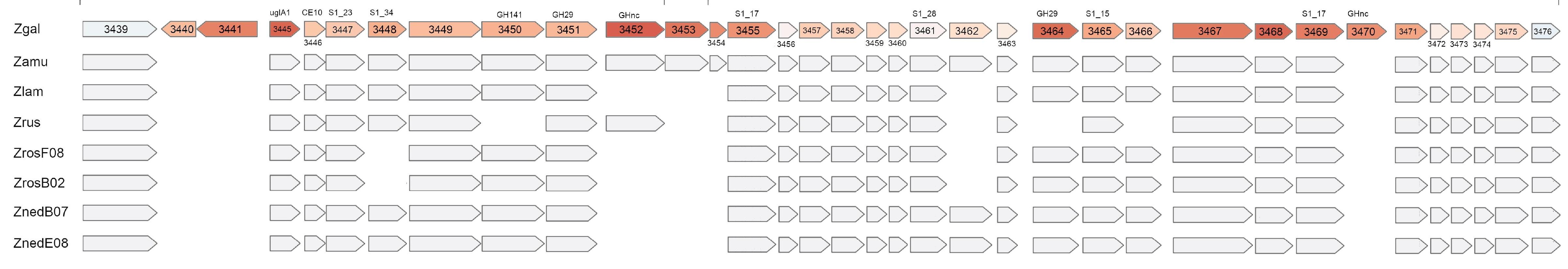

